\title{
GLOSSARY OF PERSONS
}

Abbot, George 1562-1633 $4^{\text {th }}$ Chancellor of Trinity College, Dublin, and Archbishop of Canterbury from 1611 to 1633, son of Alice Marsh and George Abbot. Never married. Acuña, Diego Sarmiento de 1567-1526 Count of Gondomar, Spanish ambassador to England 1613-1622.

Aglionby, Mary d. 1680 Daughter of Jane Brougham and Edward Aglionby. Married 1: John Sandford of Askham, 2: Mr Winch.

Amherst, Richard 1565-1632 Lawyer and steward to Sackvilles, Earls of Dorset, until his death.

Anna Maria of Austria 1601-1666 Queen consort of France and Navarre, Queen Regent for Louis XIV of France. Daughter of Philip III of Spain and Margaret of Austria. Married Louis XIII of France.

Annesley, Grace b. c. 1570 Daughter of Elizabeth More and Sir Brian Annesley of Kent. Married Sir John Wildgoose.

Askew, Mr active 1616 Gentleman, Anne gives him money to travel to Jerusalem.

Atkins, Edward active 1653-1666 Judge of the Common Pleas and assizes.

Atkinson, John d. 1733 Alderman and mayor of Appleby several times.

Bacon, Anne d. 1680 Daughter of Jane Cornwallis and Sir Nathaniel Bacon. Married 1:

Thomas Meautys, 2: Harbottle Grimston, $2^{\text {nd }}$ Baronet Grimston.

Bacon, Francis 1561-1626 Baron Verulam and $1^{\text {st }}$ Viscount St Alban, son of Anne Cooke and Sir Nicholas Bacon. Married Alice Barnham.

Baker, $\mathrm{Mr}$ A servant to Richard Sackville.

Baker, Sibilla active 1660 Gentlewoman servant to Anne's granddaughter, Frances Tufton.

Barlow, Frances c. 1550 Daughter of Agatha Wellesbourne and William Barlow, Bishop of Chichester. Married Tobias Matthew, Archbishop of York.

Barnham, Alice 1592-1650 Daughter of Dorothy Smith and Benedict Barnham.

Married 1: Francis Bacon, $1^{\text {st }}$ Viscount St Alban, 2: Sir John Underhill.

Barrett, Elizabeth b. c. 1590 Daughter of Lettice Barrett and Sir Francis Knollys of Reading Abbey. Married Robert Hammond.

Basket, Peter active 1616-1624. Gentleman of the Horse at Knole.

Bathurst, Mrs active 1616 Gentlewoman in charge of the infant Margaret Sackville.

Batters, Mrs active 1619 Servant to Anne Sackville, Lady Beauchamp. She enters the Knole household in 1619.

Beat, $\mathrm{Mr}$ A traveller who visits Anne Clifford in 1619.

Beaumont, Mary 1604-1654 Daughter of Mary Pierrepont and Sir Francis Beaumont. Married Spencer Compton, $2^{\text {nd }}$ Earl of Northampton. Her son, James, $3^{\text {rd }}$ Earl of Northampton, married Anne's daughter Isabella.

Bellasis, James b. 1562 A tenant of Hallrigg, Westmorland, son of Margaret Fairfax and William Bellasis, connected to Anne through the Threlkelds. 
Benn, Annabel 1606-1698 Countess of Kent, daughter of Jane Evelyn and Anthony Benn. Married 1: Anthony Fane, 2: Henry Grey, $10^{\text {th }}$ Earl of Kent. Nicholas Tufton, Anne's eldest grandson, hoped to marry her but she never consented.

Benson, Henry active 1670-1676 Called both herdsman and steward of Southfield near Brougham.

Bernard, Robert 1601-1666 $1^{\text {st }}$ Baronet, lawyer, son of Mary Woodhouse and Francis Bernard. Married 1: Elizabeth Tallakerne, 2: Elizabeth Altham. Part of Anne's legal team in her disputes with her tenants. Connected to Anne through the marriage of his daughter to a St John.

Bertie, Henry d. 1655 Of Lound, son of Mary De Vere and Peregrine Bertie, $13^{\text {th }}$ Baron Willoughby. Married Dorothy Corbet.

Bertie, Robert 1582-1642 $14^{\text {th }}$ Baron Willoughby and $1^{\text {st }}$ Earl of Lindsey, son of Mary De Vere and Peregrine Bertie, $13^{\text {th }}$ Baron Willoughby. Married Elizabeth Montagu (d. 1654), daughter of Elizabeth Harrington and Sir Edward Montagu.

Billingsley, Bridgett active 1666 Gentlewoman servant to Mary Tufton, Anne's granddaughter, likely daughter or granddaughter of Thomas Billingsley, gentleman servant to Richard Sackville at Knole, and later governor of two of Anne Clifford's Tufton grandsons.

Billingsley, Thomas c. 1600 - after 1666 Knight, gentleman servant at Knole. He accompanied Anne's Tufton grandsons to Europe.

Billingsley, Tobias active 1616-1624 Richard Sackville's gentleman servant, likely connected to Sir Thomas Billingsley.

Bird, James active $\mathbf{1 6 6 0}$ and $\mathbf{1 6 7 6}$ Of Brougham Hall, lawyer for Anne, also steward for John Lowther. He had nine sons. He was also active in the politics of Westmorland.

Birkbeck, Thomas d. 1676 Of Hornby Hall, Penrith, son of Eleanor Poole and Henry Birkbeck. Married Margaret Catterick. Hornby Hall was given to the Birkbecks by Henry Clifford, $2^{\text {nd }}$ Earl of Cumberland, in 1552.

Birkbeck, William d. 1698 Of Deep Gill, Mallerstang, son of Isabel and Geoffrey Birkbeck. Married Isabel Bell.

Blamire, Jeffrey d. 1678 Anne's tenant farmer who dined weekly at Brougham in the last months of Anne's life.

Blenkinsop, Francis b. c. 1630 Son of Anne Osbaldston and Thomas Blenkinsop.

Blenkinsop, Katherine d. 1675 Daughter of Anne Osbaldston and Thomas Blenkinsop. Never married.

Blenkinsop, Thomas c. 1595 - c. 1675 Gentleman of Helbeck Hall, son of Margery Wykeliffe and Henry Blenkinsop and ward of Margaret Russell, Anne's mother. Married Anne Osbaldston, daughter of Sir Edward Osbaldston. He was a Catholic and his sister was a nun in Lisbon, Portugal.

Blount, Charles 1563-1606 $8^{\text {th }}$ Baron Mountjoy and later $1^{\text {st }}$ Earl of Devonshire, son of Catherine Leigh and James Blount, $6^{\text {th }}$ Baron Mountjoy. Married Christiana Bruce.

Bonham, Dorothy d. 1641 Daughter of Charles Bonham. Married William Selby.

Bosville (Boswell), Ralph d. 1682 Knight of Brabourne House, Sevenoaks, Kent.

Bourchier, Francis 1587-1612 Daughter to Elizabeth Russell and William Bourchier. Never married. First cousin to Anne, who erected a monument for her in the Bedford Chapel at Chenies, Buckinghamshire.

Bourchier, William 1557-1623 $3^{\text {rd }}$ Earl of Bath, son of Frances Kitson and John Bourchier, Lord Fitzwarren. Married Anne's aunt Elizabeth Russell. 
Bourchier, Richard b. c. 1585 Lord Fitzwarren, son of William Bourchier and Elizabeth Russell. Never married.

Boyle, Charles 1639-1694 $3^{\text {rd }}$ Baron Clifford of Londesborough, $3^{\text {rd }}$ Viscount Dungarvan, son of Elizabeth Clifford and Richard Boyle. Married 1: Jane Seymour, daughter to William Seymour, $2^{\text {nd }}$ Duke of Somerset; 2: Arethusa Vernon.

Boyle, Charles c. 1669-1704 $4^{\text {th }}$ Viscount Dungarvan, $3^{\text {rd }}$ Earl of Cork, $2^{\text {nd }}$ Earl of Burlington, son of Jane Seymour and Charles Boyle, $3^{\text {rd }}$ Viscount of Dungarvan. Married Juliana Noel.

Boyle, Elizabeth 1662-1703 Countess of Barrymore, daughter of Jane Seymour and Charles Boyle, $3^{\text {rd }}$ Viscount Dungarvan. Married James Barry, $4^{\text {th }}$ Earl of Barrymore.

Boyle, Elizabeth d. 1725 Daughter of Elizabeth Clifford and Richard Boyle. Married Nicholas Tufton, $3^{\text {rd }}$ Earl of Thanet, son of Margaret Sackville and Anne's grandson.

Boyle, Frances b. c. 1640 Daughter of Elizabeth Clifford and Richard Boyle. Married 1: Colonel Francis Courtenay, 2: Wentworth Dillon, $4^{\text {th }}$ Earl of Roscommon.

Boyle, Henrietta 1646-1687 Daughter of Elizabeth Clifford and Richard Boyle. Married Lawrence Hyde, $1^{\text {st }}$ Earl of Rochester.

Boyle, Henry 1669-1725 $1^{\text {st }}$ Baron Carleton, son of Jane Seymour and Charles Boyle, $3^{\text {rd }}$ Viscount of Dungarvan. Never married.

Boyle, Mary Anne d. 1671 Daughter of Elizabeth Clifford and Richard Boyle. Married Edward Montagu, 2nd Earl of Sandwich.

Boyle, Richard c. 1641-1665 Son of Elizabeth Clifford and Richard Boyle. He died at the Battle of Lowestoft.

Boyle, Richard 1612-1698 $1^{\text {st }}$ Earl of Burlington and $2^{\text {nd }}$ Earl of Cork, Lord Clifford of Londesborough. Married Elizabeth Clifford and heir of Henry Clifford, $5^{\text {th }}$ Earl of Cumberland.

Bracken, John active 1665-1719. Painter, of London. He produced portraits (and often copies of portraits) for a number of north-eastern families including Anne Clifford, the Flemings, the Fletchers and others.

Bradford Adam active 1617-1624 A servant (barber) at Knole.

Braganza, Catherine 1638-1705 Infanta of Portugal, Queen consort of England, Scotland and Ireland, daughter of Luisa de Guzmán and John, $8^{\text {th }}$ Duke of Braganza. Married Charles II, King of England.

Bricknell, Jane d. c. 1670 Anne's elderly servant who lodged in a room at Brougham.

Bromedish, Mrs active 1619 Gentlewoman servant to Anne at Knole.

Bromley, Edward 1563-1626 Knight and Baron of the Exchequer, son of Joan Waverton and Sir George Bromley of Hallon, Shropshire. Married Margaret Lowe, heiress of Nicholas Lowe of Tymore.

Brooke, Henry 1564-1619 $11^{\text {th }}$ Baron Cobham, son of Frances Newton and William Brooke, $10^{\text {th }}$ Baron Cobham. Married Frances Howard, Countess of Kildare and daughter of Charles Howard, ${ }^{\text {st }}$ Earl of Nottingham.

Browne, Elizabeth d. 1616 Daughter of Jane Radcliffe and Anthony Browne, $1^{\text {st }}$ Viscount Montagu. Married Robert Dormer, $1^{\text {st }}$ Baron.

Bruce, Christiana 1595-1674 Daughter of Magdalene Clark and Edward Bruce, $1^{\text {st }}$ Lord Kinloss. Married William Cavendish, $2^{\text {nd }}$ Earl of Devonshire.

Bruce, Janet b. c. 1596 Daughter of Magdalene Clark and Edward Bruce, $1^{\text {st }}$ Lord Kinloss. Married Thomas Dalyell of The Binns.

Bruce, Thomas 1599-1663 $3^{\text {rd }}$ Lord Kinloss and $1^{\text {st }}$ Earl of Elgin, son of Magdalene Clark 
and Edward Bruce, $1^{\text {st }}$ Lord Kinloss. Married 1: Anne Chichester, 2: Diana Cecil.

Brydges, Elizabeth c. 1578-1617 Maid of Honour to Elizabeth I, daughter of Frances Clinton and Giles Brydges, $3^{\text {rd }}$ Baron Chandos. Married Sir John Kennedy.

Brydges, Frances 1580-1663 Daughter of Mary Hopton and William Brydges $4^{\text {th }}$ Baron Chandos. Married 1: Thomas Smith, 2: Thomas Cecil, $1^{\text {st }}$ Earl of Exeter.

Brydges, Katherine 1580-1657 Daughter of Frances Clinton and Giles Brydges, $3^{\text {rd }}$ Baron Chandos. Married Francis Russell, $4^{\text {th }}$ Earl of Bedford, Anne's first cousin.

Buchanan, Charles b. 1661 Son of Emma Burton and James Buchanan. Ordained Deacon, 1681.

Buchanan, James, d. 1680 Vicar of St Lawrence's, Appleby and Rector of Dufton, son of George Buchanan, Vicar of Kirkby Lonsdale. Married Emma Burton.

Buckle, William active 1675-1676 Anne's scullery boy.

Burke, Richard 1572-1635 $\quad 4^{\text {th }}$ Earl of Clanricarde, son of Honora Burke (daughter of John Burke) and Ulrick Burke, $3^{\text {rd }}$ Earl of Clanricarde. Married Frances Walsingham.

Burton, Edward 1566-1638 Knight, Rector of Broadwater, Sussex. Married Mary Perrin.

Burton, Katherine 1599-1660 Anne's gentlewoman servant at Knole, daughter of Mary Perrin and Sir Edward Burton.

Butler, Thomas 1634-1680 $6^{\text {th }}$ Earl of Ossory, son of Elizabeth Preston and James Butler, $1^{\text {st }}$ Duke of Ormonde. Married Emilia van Nassau-Beverweerd, a Dutch aristocrat.

Byfield, Rev. active 1664 Chaplain to the Richard Boyle, Earl of Cork.

Caldicott, Matthew active 1616-1624 One of Richard's Sackville closest gentleman servants who vied with Anne for authority in the family at Knole. He was one of the witnesses of Richard's Sackville's will.

Calvert, George 1579-1631 $\quad 1^{\text {st }}$ Baron Baltimore, son of Alice Crossland and Leonard Calvert, a tenant of Whartons. Married Anne Mynne. Became Secretary of State in 1619 .

Care, Mistress active 1619 Likely the wife of Richard Sackville's servant and tenant Robert Care.

Care, Robert active 1616-1624 Richard Sackville's servant and tenant.

Carew, George 1555-1629 Baron Carew of Clopton, $1^{\text {st }}$ Earl of Totnes, son of Catherine Huddesfield and Dr George Carew, Dean of Windsor. Married Joyce Clopton.

Carey, Frances b. 1571 Daughter of Katherine Knyvet (daughter of Sir Henry Knyvet) and Sir Edward Cary. Married George Manners, $7^{\text {th }}$ Earl of Rutland.

Carey, Henry 1580-1666 $4^{\text {th }}$ Baron Hunsdon, after 1621 Viscount Rochford, and after $16281^{\text {st }}$ Earl of Dover, son of Mary Hyde and Sir John Carey, $3^{\text {rd }}$ Baron Hunsdon. Married Mary Morris.

Carey, Mary 1615-1672 Daughter of Judith Pelham and Henry Carey, $1^{\text {st }}$ Earl of Dover. Married Sir Thomas Wharton.

Carey, Philadelphia d. 1655 Daughter of Elizabeth Trevannion and Robert Carey, $1^{\text {st }}$ Earl of Monmouth. Married Sir Thomas Wharton.

Carey, Robert 1560-1639 $1^{\text {st }}$ Earl of Monmouth, son of Anne Morgan and Henry Carey, $1^{\text {st }}$ Baron Hunsdon. Married Elizabeth Trevannion.

Carlton, Jane d. after 1676. Daughter of Nichola Elliot and Gerald Carleton.

Carlton, Robert d. after $\mathbf{1 6 7 6}$ Son of Barbara Delaval and William Carleton. 
Carlton, William 1607-1665 Knight, of Penrith, son of Nichola Elliot and Gerald Carleton. Married 1: Dorothy Dalston, 2: Barbara Delaval.

Carlton, Thomas active 1657 One of Anne Clifford's officers in Westmorland.

Carniston, Mrs active 1603 Anne Clifford's gentlewoman servant and governess in 1603.

Carr, Anne 1615-1654 Daughter of Frances Howard, Countess of Somerset, and Robert Carr, Earl of Somerset. Married William Russell, $1^{\text {st }}$ Duke of Bedford.

Carr, Colonel active 1670 A retired military man who lived in Skipton. He may be the Scottish colonel who was proposed as Governor of Plymouth.

Carter, Dr active 1617 A minister who visits Knole in 1617.

Cary, Mary 1581-1654 Daughter of George Cary and Catherine Russell. Married John Arundell of Trerice, Cornwall.

Catterick, John d. after 1676 Of Carlton Hall, Westmorland. Married Margaret [maiden name unknown].

Catterick, Margaret d. 1685 Daughter of Margaret and John Catterick of Carleton Hall. Married Thomas Birkbeck.

Cavendish, Mary 1556-1632 Daughter of William Cavendish and Elizabeth Hardwick (Bess of Hardwick). Married her step-brother Gilbert Talbot, $7^{\text {th }}$ Earl of Shrewsbury.

Cavendish, William 1590-1628 $2^{\text {nd }}$ Earl of Devonshire, son of Anne Keighley and William Cavendish $1^{\text {st }}$ Earl of Devonshire. Married Christiana Bruce, daughter of Edward Bruce, $1^{\text {st }}$ Lord Kinloss.

Cecil, Elizabeth 1578-1646 Daughter of Dorothy Neville and Thomas Cecil, $1^{\text {st }}$ Earl of Exeter. Married 1: Sir William Hatton, 2: Sir Edward Coke.

Cecil, Elizabeth 1595-1672 Daughter of Elizabeth Drury and William Cecil, $2^{\text {nd }}$ Earl of Exeter. Married Thomas Howard, $1^{\text {st }}$ Earl of Berkshire.

Cecil, Frances d. 1643 Daughter of Elizabeth Brooke and Robert Cecil, Earl of Salisbury. Married Henry Clifford, $5^{\text {th }}$ Earl of Cumberland.

Cecil, Frances d. 1653 Daughter of Dorothy Neville and Thomas Cecil, $1^{\text {st }}$ Earl of Exeter. Married Nicholas Tufton, ${ }^{\text {st }}$ Earl of Thanet.

Cecil, John 1628-1678 $4^{\text {th }}$ Earl of Exeter, son of Elizabeth Edgerton and David Cecil, $3^{\text {rd }}$ Earl of Exeter. Married Frances Manners.

Cecil, Robert 1563-1612 $1^{\text {st }}$ Earl of Salisbury, son of Mildred Cooke and William Cecil, $1^{\text {st }}$ Baron Burghley. Married Elizabeth Brooke.

Cecil, Thomas 1542-1623 $1^{\text {st }}$ Earl of Exeter, son of Mary Cheke and William Cecil, $1^{\text {st }}$ Baron Burghley. Married 1: Dorothy Neville, 2: Frances Brydges.

Cecil, William 1590-1618 Lord de Ros, son of Elizabeth Manners, $16^{\text {th }}$ Baroness de Ros of Helmsley suo jure and William Cecil, $2^{\text {nd }}$ Earl of Exeter. Married Anne Lake.

Cecil, William 1591-1668 $2^{\text {nd }}$ Earl of Salisbury, son of Elizabeth Brooke and Robert Cecil, $1^{\text {st }}$ Earl of Salisbury. Married Catherine Howard, daughter of Thomas Howard, $2^{\text {nd }}$ Earl of Suffolk.

Chaloner, Robert d. 1621 Doctor of Divinity, and Rector of Amersham, Canon of Windsor, maintained close ties to Christ Church, Oxford.

Chaloner, Thomas 1521-1565 Knight, son of Margaret Middleton and Roger Chaloner. Married 1: Joan Cotton, 2: Audrey (or Ethelreda) Frodsham.

Chambers, Simon active $\mathbf{1 6 0 3}$ Steward to Anne Russell, Countess of Warwick.

Chantler, Nicholas d. 1620 A clergyman and schoolmaster of Lewes and Vicar of Udimore, Sussex, until 1614. 
Cheyney, Mr active 1616-1624 Gentleman servant at Knole.

Chichester, Arthur 1663-1625 $1^{\text {st }}$ Baron Chichester of Belfast, son of Gertrude Courtenay and Sir John Chichester, both of Devon. Married Lettice Perrot.

Chippindale, Anne active 1675-1676 Anne's gentlewoman, daughter of Peter Chippendale, Anne's bailiff at Skipton.

Cholmley, Henry 1609-1666 Knight and MP for Appleby, 166o Convention, son of Susan Ledgard and Sir Richard Cholmley of Whitby. Married Katherine Stapleton.

Clapham, Christopher d. 1686 Knight and MP for Appleby, 166o Convention Parliament, son of Martha Heber and George Clapham of Beamsley. Married 1: Mary Lowden, 2: Margaret Oldfield, 3: Mary Needham.

Clapham, Richard b. c. 1610, d. after 1666. Son of Martha Heber and George Clapham of Beamsley, brother to Sir Christopher Clapham. Served Anne in a variety of capacities both locally and in the South.

Clapham, Sheffield d. 1676 Son of Mary Lowden and Sir Christopher Clapham of Beamsely. Married Elizabeth Thornbury.

Clement X 1590-1676 Pope (1670-1676) born Emelio Bonaventura Altieri, son of Victoria Delfin and Lorenzo Altieri.

Clifford, Elizabeth 1613-1690 Lady Clifford of Londesborough suo jure, daughter of Frances Cecil and Henry Clifford, $5^{\text {th }}$ Earl of Cumberland. Married Richard Boyle, $2^{\text {nd }}$ Earl of Cork and $1^{\text {st }}$ Earl of Burlington.

Clifford, Francis 1559-1641. $\quad 4^{\text {th }}$ Earl of Cumberland, son of Anne Dacre and Henry, $2^{\text {nd }}$ Lord Clifford. Married Grisold Hughes.

Clifford, George 1561-1626. $\quad 3^{\text {rd }}$ Earl of Cumberland, son of Anne Dacre and Henry Clifford, $2^{\text {nd }}$ Earl of Cumberland. Married: Margaret Russell.

Clifford, Henry 1493-1542 $1^{\text {st }}$ Earl of Cumberland, son of Anne St John and Henry, $10^{\text {th }}$ Lord Clifford. Married 1: Margaret Talbot, 2: Margaret Percy.

Clifford, Henry 1517-1570 $2^{\text {nd }}$ Earl of Cumberland, son of Margaret Percy and Henry Clifford, $1^{\text {st }}$ Earl of Cumberland. Married 1: Eleanor Brandon, daughter to Mary Tudor, youngest sister of Henry VIII, 2: Anne Dacre.

Clifford, Henry 1591-1643 $5^{\text {th }}$ Earl of Cumberland, son of Grisold Hughes and Francis Clifford. Married Frances Cecil.

Clifton, Anne b. c. 1625 Daughter of Frances Clifford and Gervase Clifton. Married Sir Francis Rodes of Barlborough.

Coke, Edward 1552-1634 Knight, Attorney General and Chief Justice of the King's Bench, son of Winifred Knightley and Edward Coke. Married 1. Bridget Paston, 2. Elizabeth Hatton.

Coleby, John active 1655-1665 Of Coleby Hall, Askrigg, Yorkshire, son of Mary and John Coleby. Married and had at least a daughter, Anne, who married Sir James Metcalfe of Nappa.

Compton, Alethea 1661-1678 Daughter of Isabella Sackville and James Compton, $3^{\text {rd }}$ Earl of Northampton, and Anne's granddaughter. Married Sir Edward Hungerford.

Compton, Anne d. 1675 Marchioness of Clanricarde, daughter of Elizabeth Spencer and William Compton, $1^{\text {st }}$ Earl of Northampton. Married Ulrick Burke, $1^{\text {st }}$ Marquess of Clanricarde.

Compton, Henry c. 1584 - c. 1659 MP for East Grinstead, son of Anne Spencer and Sir Henry Compton, $1^{\text {st }}$ Baron Compton. Married his step-sister, Cecily Sackville. 
Compton, Henry 1632-1713 Bishop of Oxford and later Bishop of London, son of Mary Beaumont and Spencer Compton, $2^{\text {nd }}$ Earl of Northampton. Never married.

Compton, James 1622-1681 $3^{\text {rd }}$ Earl of Northampton, son of Mary Beaumont and Spencer Compton, $2^{\text {nd }}$ Earl of Northampton. Married 1: Isabella Sackville, Anne's daughter, 2: Mary Noel.

Concini, Concini 1575-1617 Marquis d'Ancre. A Florentine who went to France with Marie de Medici upon her marriage to Henri IV of France. Married Lenora Dori. He was murdered apparently with the consent of Louis XIII. Lenora was executed for sorcery.

Conniston, John active 1620 Servant in the Knole household.

Conniston, Ralph active 1612-1616 Gentleman servant to Margaret Russell in Westmorland. Likely related to Walter 'Wat' Conniston.

Conniston, Walter, 'Wat' active 1616 Gentleman servant of Anne's at Knole, likely related to Ralph Conniston.

Cook, John active $\mathbf{1 6 1 7}$ A servant at Knole.

Cooling, Peter active 1619 Anne intercedes on his behalf for a post as gunner at Carlisle.

Cope, Isabel 1590-1638 Daughter of Dorothy Grenville and Sir Walter Cope. Married Henry Rich, $1^{\text {st }}$ Earl of Holland.

Corbet, Elizabeth d. 1623 Daughter and heir of Robert Corbet of Moreton Corbet. Married Sir Henry Wallop.

Cornwallis, Frances 1573-1625 Daughter of Lucy Neville and Sir William Cornwallis. Married Sir Edmund Withypole.

Cornwallis, Thomas d. 1618 Knight, groom-porter 1597-1618, son of Margaret Lowthe and Richard Cornwallis. Married Elizabeth Molineux.

Cotton, John b. 1613 A Roman Catholic, imprisoned (1613-1619) falsely as the author of the seditious pamphlet Balaam's Ass.

Cotton, Mary d. 1580 Daughter of Mary Olney and Sir George Cotton. Married Henry Grey, $6^{\text {th }}$ Earl of Kent.

Coventry, George 1628-1680 $\quad 3^{\text {rd }}$ Baron Coventry, son of Mary Craven and Thomas Coventry, $2^{\text {nd }}$ Baron Coventry. Married Margaret Tufton.

Coventry, Henry 1619-1686 Secretary of State, son of Elizabeth Aldersley and Thomas Coventry, $1^{\text {st }}$ Baron Coventry. Never married.

Coventry, John 1654-1687 $4^{\text {th }}$ Lord Coventry, son of Margaret Tufton and George Coventry. Never married.

Coventry, Thomas 1578-1640 $1^{\text {st }}$ Baron Coventry, Lord Keeper of the Great Seal, son of Margaret Jeffreys and Sir Thomas Coventry. Married 1: Sarah Sebright, 2: Elizabeth Aldersley.

Coventry, Thomas 1606-1661 $2^{\text {nd }}$ Baron Coventry, son of Sarah Sebright and Thomas Coventry, ${ }^{\text {st }}$ Baron Coventry. Married Mary Craven.

Crawley, Mrs active 1619 Anne's gentlewoman servant at Knole.

Crew, Ranulph 1558-1646 Chief Justice of the King's Bench, son of Alice Mainwaring and John Crew of Nantwich. Married 1: Julia Clipsby, 2: Julian Fasey.

Croke, Unton 1596-1671 Serjeant at Law, assize judge and MP, son of Katherine Blount and Sir John Croke. Married Anne Hore.

Crow, Charles 1630-1682 Vicar of Warcop, son of Edward Crow. His son Charles Crow became Bishop of Cloyne. 
Curvett, Acton active 1616-1624 Chief footman at Knole.

Curzon, George d. 1623 Knight, of Croxall Hall, son of Katherine Babington and George Curzon. Married Mary Leveson.

Curzon, Mary 1585-1645 Governess to the royal children, including Prince Charles and Prince James. Daughter of Mary Leveson and Sir George Curzon. Married Edward Sackville, $4^{\text {th }}$ Earl of Dorset.

Dacre, Anne 1557-1630 Poet, daughter of Elizabeth Leyburne and Thomas Dacre, $4^{\text {th }}$ Baron Dacre. Married her stepbrother Philip Howard, Earl of Arundel.

Dacre, William 1493-1563 Son of Elizabeth Greystoke and Thomas Dacre, $2^{\text {nd }}$ Baron. Married Elizabeth Talbot.

Dallison, Maximillian 1577-1631 Knight and High Sheriff of Kent, son of Silvestra Dene and William Dallison, stepson to William Lambarde the antiquarian. Married 1: Paulina Sondes, 2: Mary Spencer.

Dalston, Bridget d. after 1668 Daughter of Sir George Dalston. Married Thomas Sandford, $1^{\text {st }}$ Baronet.

Dalston, Christopher 1638-1697 Son of Lucy Fallowfield and Sir John Dalston. Married Bridget Fletcher.

Dalston, John 1611-1692 Knight, MP for Appleby, son of Anne Hutton and Christopher Dalston of Acorn Bank. Married Lucy Fallowfield.

Dalton, John d. c. 1676 Vicar of Shap 1668-1671.

Darby, John active 1657 Anne's officer in Westmorland.

Darcy, Elizabeth d. 1617 Daughter of Frances Rich and John Darcy, $2^{\text {nd }}$ Baron of Chiche. Married John Lumley, $1^{\text {st }}$ Baron.

Dargue, Margaret active 1669-1676 Anne's laundry maid, maybe daughter of Jane Dargue, a resident of Anne's almshouse in Appleby.

Dargue, William active 1669-1676 Anne's kitchen servant or scullery man, maybe son of Jane Dargue, a resident of Anne's almshouse in Appleby.

Davis, Mr active 1619-1624 Gentleman, possibly one of the Inner Temple lawyers Charles or John Davis - mentioned in Richard Sackville's will.

Davis, Mrs active 1619 Gentlewoman servant of Anne Clifford's at Knole in 1619, possibly the wife of one of Inner Temple lawyers - Charles or John Davis - mentioned in Richard Sackville's will.

Dawson, Richard active 1616-1617 A servant of Margaret Russell. The Dawson family had served the Cliffords in the North since the time of Henry, $10^{\text {th }}$ Lord Clifford.

De Vere, Bridget 1584-1631 Daughter of Anne Cecil and Edward De Vere, $17^{\text {th }}$ Earl of Oxford. Married Francis Norris, $1^{\text {st }}$ Earl of Berkshire.

De Vere, Elizabeth 1575-1627 Daughter of Anne Cecil and Edward de Vere, 17th Earl of Oxford. Married William Stanley, $6^{\text {th }}$ Earl of Derby.

De Vere, Susan 1587-1629 Daughter of Anne Cecil and Edward De Vere, $17^{\text {th }}$ Earl of Oxford. Married Philip Herbert, Earl of Montgomery later Earl of Pembroke as his first wife.

Delaval, Barbara d. after 1676 Daughter of Barbara Selby and Robert Delaval. Married William Carlton.

Demaine, Dorothy, the younger active 1668-1676 Anne's laundry (household) maid, from the Demaine family of Barden, Yorkshire, daughter of Dorothy Demaine and George Demaine, both of whom served as Anne's housekeepers at Barden Tower.

Demaine, George active 1668-1676 Housekeeper of Barden Tower. Married likely 
Dorothy. His eldest son is William who lives in Barden Forest, had son John also, and likely several daughters who served Anne as laundry (or household) maids.

Dennison, Robert active 1670-1676 A labourer of Brougham, son according to Anne of a deaf woman.

Devereux, Dorothy 1564-1619 Countess of Northumberland, daughter of Lettice Knollys and Walter Devereux, $1^{\text {st }}$ Earl of Essex. Married 1: Sir Thomas Perrot, 2: Henry Percy, $9^{\text {th }}$ Earl of Northumberland.

Devereux, Frances 1599-1674 Countess of Somerset, daughter of Frances Walsingham and Robert Devereux $2^{\text {nd }}$ Earl of Essex. Married William Seymour, $2^{\text {nd }}$ Duke of Somerset.

Devereux, Penelope 1562-1607 Daughter of Lettice Knollys and Walter Devereux, $1^{\text {st }}$ Earl of Essex. Married 1: Sir Robert Rich, 2: her lover Charles Blount.

Devereux, Robert 1591-1646 $3^{\text {rd }}$ Earl of Essex, son of Frances Walsingham and Robert Devereux, $2^{\text {nd }}$ Earl of Essex. Married 1: Frances Howard, later Countess of Somerset, marriage annulled, 2: Elizabeth Paulet.

Dick, Grey active 1616 A servant of Richard Sackville at Knole

Digby, Anne d. 1612 Daughter of Anne Cope and Kenelm Digby of Stoke Dry (d. 1590). Married Sir Edward Watson of Rockingham Castle.

Digby, John 1580-1653 $1^{\text {st }}$ Earl of Bristol, son of Abigail Heveningham and Sir George Digby. Married Beatrice Walcott.

Domville, Robert b. c. 1590 Clergyman, B.A. from Trinity College, Cambridge, curate at Bolton, Rector of Waldron, Sussex, in 1617.

Dorothy Bonham 1572-1641 Daughter and heir of Charles Bonham of Malling, Kent. Married Sir William Selby III.

Douglas-Hamilton William 1634-1694 $1^{\text {st }}$ Marquess of Douglas and Duke of Hamilton, son of Mary Gorden and William Douglas. Married Anne Hamilton, $3^{\text {rd }}$ Duchess Hamilton suo jure. Duke of Hamilton through his wife, and took her surname, as did their children.

Drax, Henry 1641-1682 Son of Meliora Horton and Sir James Drax. Married 1: Frances Tufton, 2: Dorothy Lovelace.

Drummond, Jane c. 1585-1643 Mistress of the Robes to Queen Anne, daughter of Elizabeth Lindsay and Patrick Drummond, $3^{\text {rd }}$ Lord Drummond. Married Robert Ker, Earl of Roxburgh.

Drury, Elizabeth c. 1578-1654 Daughter of Elizabeth Stafford and Sir William Drury of Hawstead. Married William Cecil, $3^{\text {rd }}$ Lord Burghley and $2^{\text {nd }}$ Earl of Exeter.

Duck, Mr active 1616-1624. A page at Knole.

Dudley, John b. c. 1600 Son of Edward Sutton, $5^{\text {th }}$ Baron Dudley, with Elizabeth Tomlinson.

Dunn, William active 1616-1619 A servant to Richard Sackville. He is listed as one of the James Town Adventurers in 1620.

Duton, Henry active 1593 Knight, MP in 1593.

Earle, Erasmus 1590-1667 Serjeant at Law, son of Anne Fountaine and Thomas Earle. Married Frances Fontaine, daughter of James Fountaine.

Edge, William d. after 1676 Receiver of Anne's rents in Sussex and Kent.

Edmonds, Thomas 1563-1639 Knight, Treasurer of the Royal Household to King James, son of Joan Delbere and Thomas Edmonds. Married Magdalen Wood, co-heir of Sir John Wood. 
Edwards, Evan b. c. 1600 d. after 1650 Of Rhual in Wales, gentleman servant of Richard and Edward Sackville.

Egerton, Thomas 1540-1617 $1^{\text {st }}$ Viscount Brackley, Lord Keeper and Lord, son of Alice Sparks and Sir Richard Egerton. Married 1: Elizabeth Ravenscroft, 2: Elizabeth More, 3: Alice Spencer.

Elisabeth of France 1602-1644 Queen consort of Spain and Portugal. Daughter of Henry IV of France and Marie de Medici. Married Philip IV of Spain.

Ellis, William 1609-168o Knight, King's Serjeant of Law, assize judge, son of Jane Armstrong and Sir Thomas Ellis. Never married.

Elmes, Edmund b. c. 1520 Son of Edith Mordaunt and John Elmes. Married Alice St John.

Elmes, Thomas d. 1602 Knight, son of Alice St John and Edmund Elmes. Married Christian Hickling of Greens Norton.

Erskine, Thomas 1566-1639 $1^{\text {st }}$ Earl of Kellie, son of Margaret Home and Sir Alexander Erskine. Married 1: Anne Ogilvie, 2: Elizabeth Pierrepont, 3: Elizabeth Norreys.

Etheldreda 'Audrey' Shelton 1561-1631. Lady Walsingham, Keeper of the Queen's Wardrobe, daughter of Mary Wodehouse and Sir Ralph Shelton of Norfolk. Married Sir Thomas Walsingham of Scadbury.

Eure (or Evers), Samson b. c. 1592, d. by 1659 Serjeant at law, son of Elizabeth Lennard and Sir Francis Eure. Married Martha Cage.

Evans, Dr active 1667 Chaplain to Anne Hyde, Duchess of York. He performed the marriage of Anne Clifford's granddaughter Cecily Tufton and Christopher Hatton.

Fairer, Elizabeth d. after $\mathbf{1 6 7 6}$ Daughter of William Fairer of Shap Grange. Elizabeth Married 1: Richard Crackenthorp, 2: John Atkinson.

Fanshawe, Thomas 1632-1674 $2^{\text {nd }}$ Viscount Fanshawe, son of Elizabeth Cockayne and Thomas Fanshawe. Married 1: Katherine Ferrers, 2: Sarah Evelyn.

Fermor, Hatton d. 1640 Of Easton Neston, Sheriff of Northamptonshire, son of Sir John Fermor.

Fettiplace, Edmund 1554-1613 Knight, of Bessels Leigh, son of Elizabeth Ashfield and William Fettiplace. Married Anne Alford.

Fielding, William 1567-1643 $1^{\text {st }}$ Earl of Denbigh, son of Elizabeth Aston and Basil Fielding. Married Susan Villiers.

Finch, Catherine d. 1639 Daughter of Elizabeth Heneage, $1^{\text {st }}$ Countess of Winchilsea suo jure, and Sir Moyle Finch. Married Sir John Wentworth, $1^{\text {st }}$ Baronet of Gostfield.

Finch, Moyle 1550-1614 $1^{\text {st }}$ Baronet, son of Catherine Moyle and Sir Thomas Finch. Married Elizabeth Heneage, $1^{\text {st }}$ Countess of Winchilsea.

Fittin, Abraham active 1665-1676 Anne's coachman in Westmorland.

Fleming, Catherine b. c. 1657, d. after 1676 Daughter of Barbara Fletcher and Daniel Fleming. Married 1: Roger Moore, Recorder of Kendal, 2: Edward Wilson of Dallam Tower.

Fleming, Daniel 1633-1701 Of Rydal Hall, antiquarian, son of Alice Kirkby and William Fleming. Married Barbara Fletcher.

Fletcher, Barbara b. c. 1633, d. after 1676 Daughter of Catherine Dalston and Henry Fletcher, $1^{\text {st }}$ Baronet. Married Daniel Fleming of Rydall Hall.

Fletcher, Bridget b. c. 1644, d. after 1698 Daughter of Catherine Dalston and Henry Fletcher, $1^{\text {st }}$ Baronet. Married Christopher Dalston.

Fletcher, George $1633^{-1700} \quad 2^{\text {nd }}$ Baronet, son of Catherine Dalston and Henry Fletcher, 
$1^{\text {st }}$ Baronet, Vice Chamberlain to Queen Catherine of Braganza. Married 1: Alice Hare, 2: Mary Johnstone.

Flocknell, Mr active 1603 Gentleman servant to Anne Russell, Countess of Warwick.

Gabetis, Anne active 1650-1676 Wife of Thomas Gabetis, Anne's deputy sheriff of Westmorland.

Gabetis, Thomas 1595-1691 Anne's Deputy Sheriff of Westmorland. Married Anne (maiden name unknown).

Gamage, Barbara 1562-1621 Countess of Leicester, daughter and heir of Gwenllian Powell and John Gamage of Coity Castle. Married Robert Sidney, Lord de L'Isle and Earl of Leicester.

Gently, John active 1663 Gentleman servant to John Tufton, grandson to Anne Clifford.

Gifford, Mr active 1616-1619 A servant of Richard Sackville at Knole.

Gilmore, John active 1668-1676 Gentleman, of Ramsbury, Anne's under-keeper of Whinfell forest. Married Elizabeth Nicholls.

Glemham, Thomas b. c. 1589 Knight, son of Anne Sackville, Richard Sackville's aunt, and Henry Glemham. Married Catherine Vavasour.

Golding, Humphrey An associate of Anne's, possibly a servant or tenant of Margaret Russell's in Westmorland.

Goodgion, George active 1662-1676 One of Anne Clifford's chief servants, likely the son of George Goodgion, gentleman, officer of the Crimple mining works in Brougham and later clerk and overseer at Brougham.

Goodgion, Robert active 1676 Anne's tenant at Skipton, likely related to George Goodgion.

Goodwin, Jane d. 1658 Daughter and heir to Jane Wenman and Arthur Goodwin of Buckinghamshire. Married Philip, $4^{\text {th }}$ Baron Wharton.

Goodwin, Mistress active 1603 Gentlewoman servant to Anne Clifford in 1603.

Gorges, Edward c. 1582 - c. $1650 \quad 1^{\text {st }}$ Baron Gorges of Dundalk, son of Sir Thomas Gorges and Helena von Snakenborg, cousin to Anne. Married Katherine Osborne.

Gorges, Elizabeth 1578-1658 Daughter of Sir Thomas Gorges and Helena von Snakenborg. Married 1: Sir Hugh Smyth of Long Ashton, 2: Ferdinando Gorges.

Graham, Margaret d. after $\mathbf{1 6 7 6}$ Daughter of Mary Johnstone and Sir George Graham.

Grasty, Samuel b. c. 1630, d. 1683 Vicar of Brougham (including Ninekirks), son of Thomas Grasty. B.A. Brasenose College, Oxford. Married Margaret Sharshall.

Grey, Henry 1583-1639 $8^{\text {th }}$ Earl of Kent, son of Susan Cotton and Charles Grey, $7^{\text {th }}$ Earl of Kent. Married Elizabeth Talbot.

Grey, Mary d. 1702 Baroness Lucas of Crudwell suo jure, daughter and heir of Anne Neville and John Lucas, $1^{\text {st }}$ Baron Lucas. Married Anthony Grey, $11^{\text {th }}$ Earl of Kent.

Grey, Susan d. 1620 Daughter of Susan Cotton and Charles Grey, $7^{\text {th }}$ Earl of Kent. Married Sir Michael Longueville.

Griffin, Edward d. 1621 Knight, son of Lucy Palmer and Sir Edward Griffin. Married 1: Lucy Coniers, 2: Anne Smith, 3: Elizabeth Chambers. Married his stepsister Lucy Coniers.

Grimston, Harbottle $1603-1685 \quad 2^{\text {nd }}$ Baronet, son of Elizabeth Coppenger and Sir Harbottle Grimston, $1^{\text {st }}$ Baronet. Married 1: Mary Croke, 2: Anne Bacon. 
Grimston, Samuel 1643-1700 $3^{\text {rd }}$ Baronet, son of Mary Croke and Harbottle Grimston, $2^{\text {nd }}$ Baronet. Married Anne Tufton.

Grosvenor, Richard 1585-1645 $1^{\text {st }}$ Baronet, son of Christian Brooke and Richard Grosvenor of Eaton. Married 1. Lettice Cholmley, 2: Elizabeth Wilbraham, 3: Elizabeth Warburton.

Guy, Edward active 1671-1676 A Quaker and merchant of both foodstuffs and highquality items like silver and paper. Married a Garth.

Hale, Matthew 1609-1676 Baron of the Exchequer, son of Joan Poyntz and Robert Hale. Married 1: Anne Moore, 2: Anne Bishop. One of Anne's lawyers.

Hall, John active 1665-1676 Chief groom of Anne's stables in Westmorland.

Hall, Margaret active 1619 Cousin to Anne, from Guildford.

Hammond, Robert c. 1594-1627 Son of Mary Harrison and John Hammond. Married Elizabeth Knollys.

Harington, Theodosia d. 1650 Daughter of Lucy Sidney of Penshurst and John Harington. Married Edward Sutton, $5^{\text {th }}$ Baron Dudley.

Harington, Lucy 1581-1627 Lady of the Privy Chamber to Queen Anne, daughter of Anne Kelway and John Harington, $1^{\text {st }}$ Baron Harington. Married Edward Russell, $3^{\text {rd }}$ Earl of Bedford.

Harmon, Thomas active 1616-1624 Gentleman servant at Knole.

Harrison, Christopher active 1670s Vicar of Brough. Married to a Farrand

Harrison, Margaret b. c. 1635, d. 1677 Daughter of Margaret Darcy and Sir Thomas Harrison. Married Sir Richard Musgrave, $3^{\text {rd }}$ Baronet of Hartley Castle.

Harrison, Mistress Anne's gentlewoman servant in 1603 .

Harrison, Robert, active 1668-1676 Anne's housekeeper of Brough Castle, also does tailoring work for her.

Harrison, Thomas 1616-1660 A Parliamentarian army officer and regicide, son of Mary and Richard Harrison, mayor of Lyme, Staffordshire. Married his cousin Catherine Harrison.

Hart, Percival 1559-1642 Knight of Lullingstone Castle, son of Elizabeth Bowes and Sir George Hart. Married 1: Mary Harrison, 2: Anne Manwood, 3: Jane Stanhope.

Hasell, Edward 1642-1707 Knight, son of Rev. Edward Hasell and Martha Smyth. Married 1: Jane Fetherstonhaugh, 2: Dorothy Williams.

Hastings, Elizabeth 1556-1621 Countess of Worcester, daughter of Francis Hastings, $2^{\text {nd }}$ Earl of Huntingdon, and Catherine Pole. Married Edward Somerset, $4^{\text {th }}$ Earl of Worcester.

Hatfield, Henry active 1660 Gentleman servant to Anne's grandson, John Tufton.

Hatton, Christopher 1605-1670 $1^{\text {st }}$ Baron Hatton, son of Sir Christopher Hatton and Alice Fanshawe. Married Elizabeth Montagu. He was a collector of books and antiquities and contributed material to Anne Clifford's Great Books of Record.

Hatton, Christopher 1632-1706 $1^{\text {st }}$ Viscount Hatton and Governor of Guernsey, son of Elizabeth Montagu and Christopher Hatton, $1^{\text {st }}$ Baron Hatton. Married 1: Cecily Tufton, 2: Frances Yelverton, 3: Elizabeth Haslewood.

Hatton, Frances 1590-1623 Daughter and heiress of Elizabeth Gawdy and Sir William Hatton. Married Sir Robert Rich, $2^{\text {nd }}$ Earl of Warwick.

Hawkridge, Mrs Gentlewoman servant to Anne Clifford in 1603.

Hay, James 1580-1636 $1^{\text {st }}$ Earl of Carlisle, favourite of James I and gentleman of the 
bedchamber, son of Margaret Murray and George Hay, $1^{\text {st }}$ Earl of Kinnoull. Married 1: Honoria Denny, 2: Lucy Percy.

Herbert, James 1623-1677 MP, son of Susan De Vere and Philip Herbert, $4^{\text {th }}$ Earl of Pembroke. Married Jane Spiller.

Heneage, Elizabeth 1556-1634 $1^{\text {st }}$ Countess of Winchilsea suo jure, daughter and heir Anne Poyntz and Sir Thomas Heneage. Married Sir Moyle Finch.

Henrietta Maria of France 1609-1669 Queen Consort of England, daughter of Marie de Medici and Henry IV of France. Married Charles I of England, mother of Charles II and James II, Kings of England.

Henrietta of England 1644-1670 Duchess of Orléans, youngest daughter of Henrietta Maria of France and Charles I, King of England. Married Philippe of France, brother of Louis XIV, King of France.

Herbert, Henry c. 1538-1601 $2^{\text {nd }}$ Earl of Pembroke, son of Anne Parr (sister to Queen Catherine Parr) and Henry Herbert, $1^{\text {st }}$ Earl of Pembroke. Married Mary Sidney, poet and sister to Sir Philip Sidney.

Herbert, John Companion of Richard Sackville in 1616.

Herbert, Philip 1584-1650 $\quad 4^{\text {th }}$ Earl of Pembroke and $1^{\text {st }}$ Earl of Montgomery, son of Mary Sidney and Henry Herbert $2^{\text {nd }}$ Earl of Pembroke. Married 1: Susan De Vere, 2: Anne Clifford

Herbert, Philip 1621-1669 $5^{\text {th }}$ Earl of Pembroke, $2^{\text {nd }}$ Earl of Montgomery, son of Susan De Vere and Philip Herbert, $4^{\text {th }}$ Earl of Pembroke.

Herbert, William c. 1572-1655 $1^{\text {st }}$ Baron Powis, son of Mary Stanley and Edward Herbert. Married Eleanor Percy.

Herbert, William 1580-1630 $3^{\text {rd }}$ Earl of Pembroke, son of Mary Sidney and Henry Herbert, 2nd Earl of Pembroke. Married Mary Talbot.

Herbert, William 1641-1674 $6^{\text {th }}$ Earl of Pembroke, son of Penelope Naunton and Philip Herbert, $5^{\text {th }}$ Earl of Pembroke. Never married.

Herdson, John d. 1622 Gentleman, owner of Brome Park, Kent. His monument is in St Michael's church, Hawkinge, Kent.

Hickling, Christian d. 1635 Daughter of Frances Goodwin and William Hickling of Greens Norton. Married Thomas Elmes.

Hickling, William d. after 1606 Of Greens Norton, Northamptonshire. Married Frances Goodwin and had a daughter, Christian who married Thomas Elmes.

Hilton, Alice active 1675 Daughter of Robert Hilton of Murton.

Hilton, George active 1644-1675 Gentleman of Westmorland, served as an agent for Anne in the North in the 1640 s.

Hilton, Robert 1616-1683 Of Murton, the younger. Married Mary Hilton (her maiden name) of Hylton Castle. He was entrusted by Anne with keeping her father's tomb in good repair.

Hilton, Robert active 1675 Son of Mary and Robert Hilton of Murton.

Hilton, Thomas active 1675 Godson of Anne Clifford. Of Hilton, near Appleby. Brother of Robert Hilton the younger.

Hinde, Samuel active 1640-1670 Reverend, chaplain to Charles II, also chaplain to Margaret Sackville, son of William Hinde incumbent of Bunbury in Cheshire. Vicar of St Mary's church, Dover.

Hitchen, Mary active 1614-1619 Margaret Sackville's nursemaid at Knole. 
Hobart, Henry 1554-1625 Knight and King's attorney, judge, son of Audrey Hare and Thomas Hobart of Plumstead, Norfolk. Married Dorothy Bell.

Hodgson, Mr Westmorland manservant serving Margaret Russell. His family were tenants on the Clifford estates in Westmorland.

Hogan (or Huggins), William c. 1524 - after 1603 Held the office of Keeper of the Gardens, Hampton Court, from 1561 to 1588.

Holles, Denzil 1599-1680 $1^{\text {st }}$ Baron, son of Anne Stanhope and John Holles, $1^{\text {st }}$ Earl of Clare. Married 1: Dorothy Ashley, 2: Jane Covert, 3: Esther Le Lou.

Home, Alexander c. 1566-1619 $1^{\text {st }}$ Earl of Home, a Scottish nobleman, son of Agnes Gray and Alexander Home, $5^{\text {th }}$ Lord Home. Married 1: Christian Douglas, 2: Mary Sutton.

Home, Elizabeth d. 1633 Daughter of Catherine Gordon and George Home, $1^{\text {st }}$ Earl of Dunbar. Married Theophilus Howard, $2^{\text {nd }}$ Earl of Suffolk.

Hookfield, Mr active 1616 A servant to Richard Sackville.

Howard, Anne 1629-1703 Daughter of Mary Butler and Edward Howard, $1^{\text {st }}$ Baron Howard of Escrick. Married Charles Howard, $1^{\text {st }}$ Earl of Carlisle.

Howard, Anne d. 1683 Daughter of Mary Widdrington and Sir Francis Howard (1588-1660). Never married.

Howard, Charles 1579-1642 $2^{\text {nd }}$ Earl of Nottingham, son of Catherine Carey, Lady of the chamber to Queen Elizabeth, and Charles Howard, $1^{\text {st }}$ Earl of Nottingham. Married 1: Charity White, 2: Mary Cokayne.

Howard, Charles 1583 - c. 1655 Son of Elizabeth Dacre and Lord Howard of Naworth Castle. Married Dorothy Widdrington.

Howard, Charles 1629-1685 $1^{\text {st }}$ Earl of Carlisle, son of Mary Eure and Sir William Howard of Naworth. Married Anne Howard, daughter of Mary Butler and Edward Howard, $1^{\text {st }}$ Baron Howard of Escrick.

Howard, Edward 1646-1692 $2^{\text {nd }}$ Earl of Carlisle, son of Anne Howard (daughter of Edward Howard, $1^{\text {st }}$ Baron Howard of Escrick) and Charles Howard, $1^{\text {st }}$ Earl of Carlisle. Married Elizabeth Uvedale.

Howard, Elizabeth c. 1586-1658 Daughter of Catherine Rich and Thomas Howard, $1^{\text {st }}$ Earl of Suffolk. Married 1: William Knollys, $1^{\text {st }}$ Earl of Banbury, 2: her lover Edward Vaux, $4^{\text {th }}$ Baron Vaux of Harrowden.

Howard, Frances 1572 - c. 1628 Countess of Kildare, maid of honour to Queen Elizabeth I, daughter of Katherine Carey and Charles Howard, $1^{\text {st }}$ Earl of Nottingham. Married 1: Henry FitzGerald, $12^{\text {th }}$ Earl of Kildare, 2: Henry Brooke, Lord Cobham.

Howard, Frances 1578-1639 Countess of Hertford and Duchess of Lennox, daughter of Thomas Howard, $1^{\text {st }}$ Viscount Howard of Bindon and Mable Burton. Married 1: Edward Seymour, $1^{\text {st }}$ Earl of Hertford, 2: Lodovic Stuart, Duke of Lennox.

Howard, Frances 1590-1632 Daughter of Catherine Knyvet and Thomas Howard, $1^{\text {st }}$ Earl of Suffolk. Married 1: Robert Devereux, $3^{\text {rd }}$ Earl of Essex (marriage annulled), 2: Robert Carr, later Earl of Somerset. Convicted of murder of Thomas Overbury.

Howard, Francis 1588-1660 Knight, of Corby Castle, son of Elizabeth Dacre and Lord Howard of Naworth Castle. Married 1: Margaret Preston, 2: Mary Widdrington.

Howard, Francis b. 1635 Captain, of Corby Castle, son of Mary Widdrington and Sir Francis Howard (1588-1660).

Howard, Henry 1628-1684 $6^{\text {th }}$ Duke of Norfolk, son of Elizabeth Stuart and Henry Howard, Earl of Arundel. Married Anne Somerset. 
Howard, Henry 1655-1701 $7^{\text {th }}$ Duke of Norfolk, son of Anne Somerset and Henry Howard, $6^{\text {th }}$ Duke of Norfolk. Married Mary Mordaunt from whom he was later divorced.

Howard, Henry Frederick 1608-1652 Earl of Arundel, son of Alethea Talbot and Thomas Howard, Earl of Arundel. Married Elizabeth Stuart.

Howard, Theophilus 1584-1640 $2^{\text {nd }}$ Earl of Suffolk, son of Catherine Knyvet and Thomas Howard, $1^{\text {st }}$ Earl of Suffolk. Married Elizabeth Home, daughter of the $1^{\text {st }}$ Earl of Dunbar. Howard, Thomas 1536-1572 $4^{\text {th }}$ Duke of Norfolk, son of Frances De Vere and poet Henry Howard Earl of Surrey. Married 1: Mary FitzAlan, heiress of Henry FitzAlan, $19^{\text {th }}$ Earl of Arundel, 2: Margaret Audley, 3: Elizabeth Leyburne. Executed in 1572 for treason.

Howard, Thomas 1561-1656 $1^{\text {st }}$ Earl of Suffolk, son of Margaret Audley and Thomas Howard, $4^{\text {th }}$ Duke of Norfolk. Married to Catherine Knyvet.

Howard, Thomas 1585-1646 $1^{\text {st }}$ Earl of Norfolk, son of Anne Dacre daughter and co-heir of Thomas, Lord Dacre and Philip Howard, $13^{\text {th }}$ Earl of Arundel. Married Alethea Talbot.

Howard, Thomas 1587-1669 $1^{\text {st }}$ Earl of Berkshire, son of Catherine Knyvet and Thomas Howard, $1^{\text {st }}$ Earl of Suffolk. Married Elizabeth Cecil.

Howard, William 1563-1640 Lord Howard of Naworth Castle, son of Margaret Audley and Thomas Howard, $4^{\text {th }}$ Duke of Norfolk. Married Elizabeth Dacre.

Howard, William 1577-1615 $3^{\text {rd }}$ Baron Howard of Effingham, son of Catherine Carey, Lady of the chamber to Queen Elizabeth, and Charles Howard, $1^{\text {st }}$ Earl of Nottingham. Married Anne St John.

Howard, William 1589-1644 Son of Elizabeth Dacre and Lord Howard of Naworth Castle. Married Mary Hungate.

Humfrey, Justina c. 1557-1627 Daughter of Joane Inkforbie and Laurence Humfrey. Married to Gaspar Dormer.

Hutchins, Mary active 1619 Nursemaid to Margaret Sackville at Knole.

Hutton, Julia b. c. 1620, d. after 1676 Daughter of Anne Briggs and Sir Richard Hutton. Married Sir Philip Musgrave, $2^{\text {nd }}$ Baronet.

Hutton, William b. c. 1550, d. 1637 Knight, of Penrith, son of Elizabeth Romney and Anthony Hutton of Hutton Hall.

Hyde, Anne 1637-1671 Daughter of Frances Aylesbury and Henry Hyde, made $1^{\text {st }}$ Earl of Clarendon. Married James, Duke of York, later James II, King of England. Mother of Mary I and Anne I, Queens of England.

Hyde, Mary d. 1627 Daughter of Leonard Hyde of Hyde Hall, Hertfordshire. Married 1: Richard Peyton, 2: John Carey, $3^{\text {rd }}$ Baron Hunsdon.

Inkforbie, Joan d. 1611. Daughter of Andrew Inkforbie of Ipswich. Married Laurence Humfrey.

Ireland, Thomas 1560-1625 Knight, son of Margaret Fox and Robert Ireland and served the Earl of Derby, represented Anne Clifford during her interview with King James about Clifford lands. Married 1: Margaret Pope, 2: Margaret Aston, 3: Susan Macwilliam, 4: Margaret Lloyd.

Irton, Dorothy active 1608-1697 A deaf woman living in Anne's almshouse at Appleby, a prodigious weaver of bone lace. Married Thomas Wybergh.

Irwin, Marianna 1603-1676 Countess of Musgrave, daughter of Sir William Irwin. Married Edmund Sheffield, $1^{\text {st }}$ Earl of Musgrave. 
Jackson, Richard active 1671-1681 Schoolmaster of Appleby, previously schoolmaster at Kendal and Bampton.

Jenkins, Jack active 1603 Musician in the service of Anne Russell, teaches Anne Clifford the bass viol.

Johnson, Thomas $\mathrm{fl} 1657$ One of Anne's officers in Westmorland. May be the husband of Anne Johnson, Anne's gentlewoman servant.

Johnson, William active 1668-1676 Housekeeper at Appleby.

Johnstone, Mary 1627-1676 Daughter of Mary Douglas and James Johnstone, Earl of Hartfell. Married 1: Sir George Graham, 2: Sir George Fletcher.

Jones, Richard active 1616 Servant to Richard Sackville at Knole.

Jordan, Isabell active 1669-1676 Anne's washerwoman in Westmorland.

Juvenal, François active 1619 Ambassador from France to England, 1619.

Kellaway, Mr d. before 1663 Of Wicks, Wiltshire. Married Elizabeth Turner.

Kendal, Mr active 1616 Servant of Margaret Russell in Westmorland.

Kidd, Mr active 1616 Servant of Margaret Russell and later Anne Clifford in Westmorland.

King, John d. 1621 Bishop of London, son of Elizabeth Conquest and Philip King. Married Joan Freeman.

Kingston, Thomas active 1668 Servant to John Gilmore in Westmorland.

Kirkhoven, Dorothea Helena d. 1564 Daughter of Katherine Stanhope and Jehan, Lord of Heenvliet. Married Charles Stanley, 8th Earl of Derby.

Kitching, Thomas active 1670-1676 Anne's tenant and also servant at Skipton.

Knightley, Richard 1533-1615 Of Fawsley Hall, son of Anne Ferrers and Valentine Knightley. Married 1: Mary Fermor, 2: Elizabeth Seymour, the daughter of Edward Seymour, $1^{\text {st }}$ Duke of Somerset.

Kniveton, St Loe 1560-1625 Antiquarian from Mercaston, Derbyshire, son of John Kniveton and Jane Leche. Worked for Margaret Russell on Clifford lawsuits.

Knollys, Lettice 1583-1655 Daughter of Margaret Cave and Sir Henry Knollys. Married William Paget, $5^{\text {th }}$ Baron Paget.

Knollys, William 1545-1632 $1^{\text {st }}$ Earl of Banbury, son of Katherine Carey and Sir Francis Knollys. Married 1: Dorothy Braye, 2: Elizabeth Howard, daughter of Thomas Howard, $1^{\text {st }}$ Earl of Suffolk.

Knyvet, Catherine, 1564 -c. 1638 Countess of Suffolk, daughter of Elizabeth Stumpe and Sir Henry Knyvet. Married 1: Richard Rich, $1^{\text {st }}$ Baron Rich, 2: Thomas Howard, $1^{\text {st }}$ Earl of Suffolk.

Knyvet, Elizabeth 1574-1630 Author of The Countess of Lincoln's Nursery (1622), daughter and heir of Elizabeth Stumpe and Sir Henry Knyvet. Married Thomas Clinton, $3^{\text {rd }}$ Earl of Lincoln.

Labourne, William active 1669-1676 Servant to John Gilmore, Keeper of Whinfell Park, may be connected to George Labourne, Sir John Lowther's servant.

Lafuente, Diego de, active 1618-1623 'Padre Maestro', confessor and informant to the Spanish Ambassador Diego Sarmiento de Acuña, Count of Gondomar. He was active in negotiations for the Spanish marriage of Charles I.

Lake, Anne c. 1604-1630. Daughter of Mary Rider and Thomas Lake. Married 1: William Cecil, $16^{\text {th }}$ Baron Ros of Helmsley, which led to Lake/Ros scandal, 2: George Romney.

Lake, Arthur 1598-1633 Knight, son of Mary Rider and Thomas Lake. Married Lettice Rich, daughter of Penelope Devereux and Robert Rich. 
Lake, Thomas 1561-1630 Knight, Secretary of State, son of Emery or Almeric Lake. Married Mary Rider.

Lane, Edward active 1617 A gentleman neighbour living near Knole.

Langhorne, Thomas d. 1693 Of Dockray Hall, Penrith, wealthy merchant, son of Thomas Langhorne.

Langworth family Of Broyle, Sussex with property in Little Horsted. Rose Durant and Arthur Langworth had five sons: John, Adam, Richard, Arthur and Nicholas.

Layfield, John c. 1563-1617 Doctor of Divinity, Fellow of Trinity College, Cambridge; Rector of St Clement Danes, London; translator for the King James Bible, son of Elizabeth and Edward Layfield. Married Bridget Robinson.

Legg, Edward active 1590-1624 Gentleman retainer and steward at Knole, long employed by the Sackvilles.

Leighton, Robert 1611-1684 Bishop of Glasgow and Principal of the University of Edinburgh, son of Alexander Leighton and a Mrs Mears. Never married.

Lennard, Pembroke c. 1576-1632 Daughter of Chrysogona Baker and Henry Lennard, $12^{\text {th }}$ Lord Dacre. Married William Brooke, $12^{\text {th }}$ Baron Cobham.

Lewis or Lewes, John active 1616 A companion of Richard Sackville in 1616.

Ligne, Charles de 1550-1616 $2^{\text {nd }}$ Prince of Arenberg, ambassador to England, son of Margaretha von der Mark, suo jure Countess of Arenberg and Jean de Ligne. Married Anne de Croy of Aarschot.

Lindsey, Edward active 1620-1624 Receiver general of Richard Sackville's revenue.

Lindsey, Mrs active 1620-1624 Wife of Edward Lindsey, a household officer of Richard Sackville's at Knole.

Littleton, Charles 1629-1716 $3^{\text {rd }}$ Baron Littleton, son of Catherine Crompton and Sir Thomas Littleton, $1^{\text {st }}$ Baron Littleton of Hagley Hall. Married 1: Catherine Fairfax, 2: Anne Temple.

Littleton, Timothy 1608-1679 Knight, Baron of the Exchequer, son of Mary Walter and Sir Edward Littleton of Henley, Shropshire. Married 1: Elizabeth (maiden name not known), 2: Elizabeth Ayliffe.

Lloyd, Mary active 1671 Daughter of a Mr Lloyd. Married Cecil Tufton.

Long, Elizabeth b. 1569 Daughter and heir of Dorothy Clarke and Henry Long of Shingay, Cambridgeshire. Married William Russell, Baron Russell of Thornhaugh.

Longueville, Michael b. 1585 Knight. Married Susan Grey, daughter of Susan Cotton and Charles Grey, 7 th Earl of Kent.

Lough, George active 1676 Clerk of Brougham.

Louis XIII, King of France 1601-1643 King of France and King of Navarre, son of Henry IV, King of France and Marie de Medici. Married Anna Maria of Austria, the Infanta of Spain and Portugal.

Lowes, Richard active 1676 Anne's housekeeper at Brougham.

Lowther, John 1605-1675 $1^{\text {st }}$ Baronet Lowther, Anne's administrator in the North (1643-1649), son of Eleanor Fleming and Sir John Lowther of Lowther Hall. Married 1: Mary Fletcher, 2: Elizabeth Hare.

Lowther, John 1628-1668 Son of Mary Fletcher and Sir John Lowther, $1^{\text {st }}$ Baronet Lowther. Married 1: Elizabeth Bellingham, 2: Mary Withins.

Lowther, John $1655^{-1700} \quad 2^{\text {nd }}$ Baronet, and later $1^{\text {st }}$ Viscount Lonsdale, son of Elizabeth Bellingham and John Lowther. Married Katherine Thynne. 
Machell, Henry 1635-1678 Steward of Anne's house and gentleman of her horse, son of Margaret Beck and Hugh Machell.

Machell, Hugh 1635-1719 Anne's receiver of rents for Temple Sowerby, son of Lancelot Machell of Crackenthorpe and Elizabeth Sleddall. Married Anne Nevinson.

Machell, Lancelot b. c. 1617, d. 1681 Of Crackenthorpe. Receiver General for

Westmorland, governor of Appleby School, son of Margaret Beck and Hugh Machell. Married Elizabeth Sleddall.

Machell, Lancelot d. after 1700 Gentleman servant to Thomas Strickland and later warden for Thomas Tufton, son of Elizabeth Sleddall and Lancelot Machell. Married Elizabeth Walker.

Machell, Susanna d. after 1681 Gentlewoman to Anne Clifford, daughter of Elizabeth Sleddall and Lancelot Machell. Unmarried before 1681.

Machell, Thomas 1647-1698 Clergyman and antiquarian, son of Elizabeth Sleddall and Lancelot Machell. Married Elizabeth Godson. His sister was gentlewoman to Anne Clifford.

Mainwaring, Henry 1587-1653 Knight, Gentleman of the bedchamber to James I, son of Anne More and Sir George Mainwaring. Married Fortune Gardiner.

Manners, Francis 1578-1632 $6^{\text {th }}$ Earl of Rutland, son of Elizabeth Charlton and John Manners, $4^{\text {th }}$ Earl of Rutland. Married 1: Frances Knyvet, 2: Cecily Tufton.

Manners, George 1580-1641 $7^{\text {th }}$ Earl of Rutland, son of Elizabeth Charleton and John Manners, $4^{\text {th }}$ Earl of Rutland. Married Frances Cary.

Manners, Katherine c. 1603-1649 Daughter of Frances Knyvet and Francis Manners, $6^{\text {th }}$ Earl of Rutland. Married George Villiers, $1^{\text {st }}$ Duke of Buckingham and James I's favourite.

Marsh, Christopher d. 1656 Gentleman servant first for the Sackvilles, and later Anne Clifford's agent and friend.

Marshall, Mr d. 1616 Richard Sackville's auditor and surveyor at Knole.

Martinozzi, Laura 1639-1687 Regent of Modena, daughter of Laura Mazarin and Count Girolamo Martinozzi. Married Alfonso IV d'Este, Duke of Modena.

Mary of Modena 1658-1718 Maria Beatrice Anna Margherita Isabella d'Este, Queen Consort of England and later called Queen over the Water. Daughter of Laura Martinozzi and Alfonso IV, Duke of Modena. Married James II, King of England.

Massey, Francis active 1675 Married the daughter of George's Hilton's wife (from a previous marriage).

Matthew, Tobias 1546-1628 Archbishop of York, son of Eleanor Croft and Sir John Matthew. Married Frances, the daughter of William Barlow, Bishop of Chichester.

Maynard, John 1604-1690 Knight, Serjeant at Law, son of Honora Arscott and Alexander Maynard. Married 1: Elizabeth Henley, 2: Jane Selhurst, 3: Margaret Gorges, 4: Mary Unton.

Medici, Cosimo III de 1642-1723 Grand Duke of Tuscany, son of Vittoria della Rovere of Urbino and Ferdinando III de Medici. Married Marguerite Louise d'Orléans, cousin to King Louis XIV of France. He travelled to England in 1669.

Metcalfe, Thomas 1579-1665 Knight, of Nappa Hall, Yorkshire, son of Elizabeth Slingsby and James Metcalfe. Married Joan Savile.

Middleton, Roger active 1668-1676 Clerk of Anne's kitchen at Appleby Castle.

Milbourne, Richard d. 1624 Chaplain to Prince Henry and Prince Charles, Bishop of Carlisle. Rector of Sevenoaks near Knole. 
Molineux, Alice d. 1643 Daughter of Frances Gerard and Sir Richard Molineux. Married Sir William Dormer.

Molineux, Roger b. 1615, d. after 1669 Colonel, son of Anne Harrington and Sir John Molineux. Married Jane Monson.

Monck, George 1608-1670 $\quad 1^{\text {st }}$ Duke of Albemarle, son of Elizabeth Smyth and Sir Thomas Monck. Married Anne Leaver. He was instrumental in the restoration of the English monarchy.

Montagu, Elizabeth 1586-1654 Daughter of Elizabeth Harrington and Sir Edward Montagu of Boughton. Married Robert Bertie, $14^{\text {th }}$ Baron Willoughby and $1^{\text {st }}$ Earl of Lindsey.

Montagu, Elizabeth 1611-1672 Daughter of Mary Whitmore and Sir Charles Montagu of Boughton. Married Christopher Hatton, $1^{\text {st }}$ Baron Hatton.

Montagu, Henry 1564-1642 $1^{\text {st }}$ Earl of Manchester, son of Elizabeth Harington and Sir Edward Montagu of Boughton. Married 1: Catherine Spenser, 2: Anne Wincot, 3: Margaret Crouch.

Montagu, Ralph 1638-1709 Ambassador to France, Duke of Montagu, son of Anne Winwood and Edward Montagu, $2^{\text {nd }}$ Baron Montagu of Boughton. Married 1: Elizabeth Wriothesley, co-heir of Thomas, $4^{\text {th }}$ Earl of Southampton, 2: Elizabeth Cavendish.

Montgomery, Margaret active 1676 Seamstress of Penrith, may be related to Fabian Montgomery, a Lowther servant.

Mordaunt, Henry 1657-1609 $4^{\text {th }}$ Baron Mordaunt, son of Elizabeth Darcy and Lewis Mordaunt. Married Margaret Compton.

Mordaunt, James c. 1588, d. after 1651 Son of Margaret Compton and Henry Mordaunt, 4th Baron Mordaunt. Married Mary Tyringham.

Mordaunt, John b. c. 1595, d. 1642. $\quad 1^{\text {st }}$ Earl of Peterborough, favourite of James I, son of Margaret Compton and Henry Mordaunt, $4^{\text {th }}$ Baron Mordaunt. Married Elizabeth Howard, daughter of William Howard, $3{ }^{\text {rd }}$ Baron Howard of Effingham.

Mordaunt, John b. c. 1637 Son of Mary Tyringham and James Mordaunt.

Morgan, Elizabeth b. c. 1590 Daughter and co-heir (with her brother Christopher) of Christopher Morgan of Mattperton, Dorset. Married 1: John Molford, 2: Sir Thomas Trenchard of Wolveton, Dorset.

Morison, Bridget d. 1623 Daughter of Dorothy Clerke and Charles Morison. Married Robert Radclyffe, $5^{\text {th }}$ Earl of Sussex.

Murgatroyd, Jacob active 1676 May be connected to Thomas Murgatroyd, vicar of and schoolmaster of Kendal.

Murray, George d. 1606 Knight, Groom of the Bedchamber, son of Sir Charles Murray of Cockpool and Margaret Somerville. He was a cousin of the Tullibardine Murrays.

Murray, William c. 1574 - c. $1627 \quad 2^{\text {nd }}$ Earl of Tullibardine, son of John Murray, ${ }^{\text {st }}$ Earl Tullibardine and Catherine Drummond. Married 1: Cecilia Wemyss, 2: Dorothea Stewart. Possibly married Euphame Littlejohn in 1593.

Musgrave, Frances b. c. 1635 Daughter of Julia Hutton and Sir Philip Musgrave, $2^{\text {nd }}$ Baronet. Married Edward Hutchinson.

Musgrave, Mary b. 1661 Daughter of Margaret Harrison and Sir Richard Musgrave, $3^{\text {rd }}$ Baronet. Married John Davison.

Musgrave, Philip 1607-1678 $2^{\text {nd }}$ Baronet, son of Frances Wharton and Sir Richard Musgrave. Married Julia Hutton of Goldsborough Hall. 
Musgrave, Richard 1635-1687 $3^{\text {rd }}$ Baronet, son of Julian Hutton and Sir Philip Musgrave, $2^{\text {nd }}$ Baronet. Married Margaret Harrison.

Musgrave, William active $\mathbf{1 6 7 6}$ Of Musgrave Hall, Justice of the Peace in Penrith, likely son of Felicia Tilliol and William Musgrave.

Nanson, Philip b. 1647, d. c. 1718 Originally from Appleby, son of Robert Nanson, elected Fellow of Queen's College, Oxford, in 1674, rector of Newnham and Dogmersfield in 1680. Married Hannah Duncombe.

Naunton, Robert 1563-1635 Knight and secretary of state, son of Elizabeth Ashby and Henry Naunton of Letheringham. Married Penelope Perrot.

Needham, John d. 1619 Knight, of Litchborough. Married Elizabeth Watson.

Neville, Cecily c. 1589-1625 Daughter of Mary Sackville and Henry Neville, $7^{\text {th }}$ Baron of Abergavenny. Married Fitzwilliam Coningsby.

Neville, Edward 1560-1622 $6^{\text {th }}$ Baron Abergavenny, son of Katherine Brome and Edward Neville. Married Rachel Lennard of Knole.

Neville, Elizabeth b. c. 1590 Daughter of Mary Sackville and Henry Neville, $7^{\text {th }}$ Baron of Abergavenny.

Neville, Henry c. 1580-1644 $7^{\text {th }}$ Baron of Abergavenny, son of Rachel Lennard and Edward Neville, $6^{\text {th }}$ Baron of Abergavenny. Married 1: Mary Sackville, daughter of Cecily Baker and Thomas Sackville, $1^{\text {st }}$ Earl of Dorset, 2: Catherine Vaux.

Neville, Mary 'Moll' b. c. 1590 Daughter of Mary Sackville and Henry Neville, $7^{\text {th }}$ Baron of Abergavenny, niece and god-daughter of Richard Sackville, part of the household at Knole.

Newdigate, Richard 1602-1678 $1^{\text {st }}$ Baron Newdigate, Common Pleas and assize judge, son of Anne Fitton and Sir John Newdigate. Married Julianna Leigh.

Nicholls, Augustine 1586-1647 Of Faxton in Northampton, keeper of the Great Seal for Prince Charles.

Nicholls, Elizabeth b. c. 1617, d. after 1676 Gentlewoman servant to Anne, entered her service as a child in 1626. Married 1: John Turner, receiver of Anne's rents in Skipton, Westmorland and later Kent, 2: John Gilmore, whom Anne appointed Keeper of Whinfell forest after the marriage.

Noel, Mary b. c. 1643, d. 1719 Daughter of Elizabeth Bertie and Baptist Noel, $3^{\text {rd }}$ Viscount Campden. Married James Compton, $3^{\text {rd }}$ Earl of Northampton.

North, Dudley 1582-1666 $3^{\text {rd }}$ Baron North, son of Dorothy Dale and Sir John North. Married Frances Brocket.

North, John c. 1583 - after 1619 Knight, son of Dorothy Dale and Sir John North, brother to Dudley North, $3^{\text {rd }}$ Baron North, and Roger North.

North, Roger 1585-1652 Captain, deputy governor of Guyana, son of Dorothy Dale and Sir John North. A merchant explorer who led an expedition to Guyana.

Ogle, Mary d. before 1657 Daughter of Thomas Ogle of Dressington, Northumberland. Married Thomas Savage, $2^{\text {nd }}$ Earl Rivers.

Oldenbarnevelt, Johan van 1547-1619 A Netherlands statesman, ambassador to England. Married to Maria van Utrecht.

Oldsworth, Arnold 1561 - c. 1633 Antiquarian, Clerk of the Hanaper, one of the executors of Anne Russell, Countess of Warwick's will, son of Tacy Porter and Edward Oldsworth. Married Lucy Barty of Antwerp.

Orfeur, Cuthbert d. 1688 Of Pryor Hall, agent for Anne Clifford in the North. Married Mary Richmond. 
Orfeur, Elizabeth b. c. 1630, d. 1705 Of Plumland Hall, daughter of Bridget Musgrave and William Orfeur. Married Thomas Sandford of Askham.

Osberton, Mr active 1617 Possibly an attorney who was later employed by James, Duke of Ormond.

Osborne, Katherine b. c. 1580, d. after 1619 Daughter and heir of Sir Robert Osborne of Kelmarsh. Married 1: Edward Haselwood, 2: Edward Gorges, $1^{\text {st }}$ Baron Gorges of Dundalk.

Otway, John 1620-1693 Knight, of Ingmire Hall, King's attorney, son of Anne Mayer and Roger Otway. Married 1: Mary Riggs, 2: Elizabeth Braithwaite. Close family connections with Cliffords.

Palmer, James 1585-1659 Vicar of St Bride's, London. He baptized Samuel Pepys at St Bride's. He founded an almshouse and free school.

Palmes, Francis, 1554-1613 Knight, of Lindley, Yorkshire, and later Lancelevy, Hampshire. Served as Sheriff of Hampshire 1600-1601.

Parker, John active 1648-1659 Serjeant at Law, one of the assize judges on the Northern circuit.

Parker, Thomas 1595-1663 Baron of Ratton, lawyer and judge, son of Katherine Temple and Sir Nicholas Parker. Married Philadelphia Lennard of Herstmonceaux Castle.

Paston, Catherine d. 1605 A lady of the Privy Chamber to Elizabeth I, daughter of Agnes Leigh and Sir Thomas Paston. Married Sir Henry Newton.

Pate, Frances active 1668-1676 Anne's chief gentlewoman. Married Edmund Pate of Burton upon Trent. Mother of Marmaduke Pate who received his B.A. from Oxford 1673.

Pattison, John active 1670-1676 Yeoman of Moorhouse. Married to Elizabeth Pattison.

Paulet, Jane active 1666 Gentlewoman servant to Cecily Tufton.

Paulet, William c. 1560-1628 $4^{\text {th }}$ Marquess of Winchester, son of Agnes Howard and William Paulet, $3^{\text {rd }}$ Marquess of Winchester. Married Lucy Cecil, daughter of Thomas Cecil, $1^{\text {st }}$ Earl of Exeter and Dorothy Neville.

Penn, Mrs active 1619 A nursery maid at Knole.

Penyston, Thomas 1591-1644 $1^{\text {st }}$ Baronet Penyston, one of Richard Sackville's retinue, son of Mary Sommer and Thomas Penyston. Married 1: Martha Temple, 2: Elizabeth Watson, 3: Anne Stonhouse. His wife Martha was one of R. Sackville's mistresses.

Percy, Dorothy 1598-1659 Daughter of Dorothy Devereux and Henry Percy, $9^{\text {th }}$ Earl of Northumberland. Married Robert Sidney, $2^{\text {nd }}$ Earl of Leicester.

Percy, Henry 1564-1632 $9^{\text {th }}$ Earl of Northumberland, called the Wizard Earl, son of Katherine Neville and Henry Percy, $8^{\text {th }}$ Earl of Northumberland. Married Dorothy Devereux.

Percy, Lucy 1598-1659 Daughter of Dorothy Devereux and Henry Percy, $9^{\text {th }}$ Earl of Northumberland. Married James Hay, $1^{\text {st }}$ Earl of Carlisle.

Perrot, Penelope d. 1655 Daughter and co-heir of Anne Cheyne and Sir Thomas Perrot. Married 1: Sir William Lower, 2: Sir Robert Naunton.

Petley, Thomas active 1617 Brewer at Knole.

Petley, William active 1617 Footman at Knole.

Petty, Thomas active 1616 Margaret Russell's footman at Brougham Castle, Westmorland.

Philip IV of Spain 1605-1665 King of Spain and Portugal, son of Philip III, King of Spain, and Margaret of Austria. Married 1: Elisabeth of France, daughter of Henry IV, 
King of France, and Marie de Medici, 2: Marianna of Austria daughter of Ferdinand III, Holy Roman Emperor, and Maria Anna of Spain.

Philippe I, Duke of Orléans 1640-1701 Duke of Anjou and after 166o Duke of Orléans, son of Anne of Austria and Louis XIII, King of France, brother to Louis XIV, King of France. Married Henrietta, daughter of Charles I, King of England.

Pickering, Christopher 1544-1621 Knight of Threlkeld, son of Winifred Threlkeld and Christopher Pickering.

Pigott, Frances d. 1615 Daughter of Thomas Pigott of Doddershall and Mary Lane. Married Sir Thomas Pope Blount.

Pond, William active 1603 Servant of Margaret Russell.

Preston, John active 1675-1676 Servant to Thomas Gabetis, Anne's under-sheriff.

Preston, Katherine active 1666 Gentlewoman servant to Anne Tufton.

Puckering, Frances d. 1619. Daughter of Jane Chowne and John Puckering. Married Sir Thomas Grantham.

Puckering, Katherine b. before 1596 Daughter of Jane Chowne and John Puckering. Married Sir Adam Newton.

Puleston, John 1583-1659 Justice of the Common Pleas, assize judge, son of Alice Lewis and Richard Puleston.

Pursglove, Dorothy d. 1691 Married Allan Smallwood, Rector of Greystoke.

Rainsford, Richard 1602-1680 Knight, Chief Justice of the Kings Bench, assize judge, son of Mary Kirton and Robert Rainsford. Married Catherine Clerke.

Raivy, John active 1616-1617 A servant of Margaret Russell.

Raleigh, Walter 1554-1618 Knight, poet, courtier and explorer, son of Catherine Champernowne and Walter Raleigh. Married Elizabeth Throckmorton.

Raleigh, Walter d. 1618 Son of Elizabeth Throckmorton and Sir Walter Raleigh. Never married, died during attack on San Thomé de Guyana.

Ram, Henry active $\mathbf{1 6 7 6}$ Of Flakebridge, Anne's tenant.

Rands, Richard Rector of St Mary the Virgin, Hartfield, East Sussex, a living in the Sackville gift.

Rawling, Cuthbert active 1675-1676 Edward Hasell's servant. May have married Bridget Fetherstonhaugh in 1699.

Reynoldson, Richard active 1675-1676 Anne's baker, brewer and porter.

Rich, Charles d. 1627 Knight, son of Penelope Devereux and Robert Rich, $1^{\text {st }}$ Earl of Warwick. Never married.

Rich, Lettice d. 1619 Daughter of Penelope Devereux and Robert Rich, $1^{\text {st }}$ Earl of Warwick. Married 1: Sir George Carey, 2: Arthur Lake.

Rich, Margaret c. 1580-1635 Daughter of Jane Machell (or Mitchell) and Richard Rich of Leighs, illegitimate son of Richard, Baron Rich. Married Sir Thomas Wroth.

Rich, Nathanial 1585-1636 Knight, son of Jane Machell (or Mitchell) and Richard Rich of Leighs, illegitimate son of Richard, Baron Rich. Never married.

Rich, Robert c. 1559-1619 $1^{\text {st }}$ Earl of Warwick, son of Elizabeth Baldry and Robert Rich, $2^{\text {nd }}$ Baron Rich. Married 1: Penelope Devereux (separated), 2: Frances Wray.

Rich, Robert 1587-1658 $2^{\text {nd }}$ Earl of Warwick, son of Penelope Devereux and Robert Rich, $1^{\text {st }}$ Earl of Warwick. Married 1: Frances Hatton, 2: Susan Rowe, 3: Eleanor Wortley.

Rider, Mary 1575-1642 Daughter of Elizabeth Stone and William Rider. Married Sir Thomas Lake. 
Rivers, George b. c. 1580 George Rivers, second son of Frances Bower and Sir George Rivers, close friend of Sackville family, executor for both Robert, $2^{\text {nd }}$ Earl of Dorset, and Richard, $3^{\text {rd }}$ Earl of Dorset.

Robbins, Tom active 1618-1619 Servant of Richard Sackville's who left after a quarrel.

Rodes, Francis 1648-1675 $3^{\text {rd }}$ Baronet, son of Anne Clifton and Francis Rodes, $2^{\text {nd }}$ Baronet of Barlborough. Married Martha Thornton.

Rodes, Jane b. c. 1649 Daughter of Anne Clifton and Frances Rodes, $2^{\text {nd }}$ Baronet of Barlborough. Married Captain William Hussey.

Roydon, Joan d. 1631 Daughter and heiress of John Roydon of Battersea. Married 1: Sir William Holcroft, 2: Oliver St John.

Rupert of the Rhine, Prince 1619-1682 Count Palatine of the Rhine, Duke of Bavaria, son of Elizabeth Stuart, daughter of James I, King of England, and Frederick V, Elector Palatine. Never married.

Russell, Anne 1549-1604 Longest-serving Gentlewoman of the Privy Chamber to Elizabeth I, daughter of Margaret St John and Francis Russell, $2^{\text {nd }}$ Earl of Bedford. Married Ambrose Dudley, Earl of Warwick.

Russell, Anne d. 1639 Daughter of Elizabeth Cook and John Russell, Anne Clifford's uncle. Married Henry Somerset, $5^{\text {th }}$ Earl of Worcester.

Russell, Edward 1572-1627 $3^{\text {rd }}$ Earl of Bedford, son of Eleanor Forster and Sir Francis Russell, Lord Russell, grandson to Francis Russell, $2^{\text {nd }}$ Earl of Bedford. Married Lucy Harington.

Russell, Edward c. 1642-1714 English politician, son of Anne Carr and William Russell, $1^{\text {st }}$ Duke of Bedford. Married Frances Williams.

Russell, Elizabeth 1555-1604 Daughter of Margaret St John and Francis Russell, 2nd Earl of Bedford. Married William Bourchier, $3^{\text {rd }}$ Earl of Bath.

Russell, Francis 1593-1641 $4^{\text {th }}$ Earl of Bedford, son of Elizabeth Long and William Russell, $1^{\text {st }}$ Baron Russell of Thornhaugh. Married Catherine Brydges.

Russell, Margaret 1560-1616 Daughter of Margaret St John and Francis Russell, 2nd Earl of Bedford. Married George Clifford, $3{ }^{\text {rd }}$ Earl of Cumberland.

Russell, William c. 1553-1613 $1^{\text {st }}$ Baron Russell of Thornhaugh, son of Margaret St John and Francis Russell, $2^{\text {nd }}$ Earl of Bedford. Married Elizabeth Long.

Russell, William 1616-1700 $1^{\text {st }}$ Duke of Bedford, son of Catherine Brydges and Francis Russell, $4^{\text {th }}$ Earl of Bedford. Married Anne Carr.

Russell, William 1639-1683 Lord Russell, son of Anne Carr and William Russell, $1^{\text {st }}$ Duke of Bedford. Married Rachel Wriothesley. Executed for treason in Rye House Plot.

Ruthven, Barbara c. 1580-1625 Lady of Queen Anne of Denmark's bedchamber, daughter of Dorothea Stewart and William Ruthven, $1^{\text {st }}$ Earl of Gowrie. Never married.

Ryder, Mr active 1616 A man who comes to Knole and share information about the death of Lady Sheffield.

Sackville, Anne 1564 - c. 1619 Daughter of Cicely Baker and Thomas Sackville, $1^{\text {st }}$ Earl of Dorset. Aunt to Richard Sackville. Married Sir Henry Glemham.

Sackville, Anne 1586-1664 Daughter of Margaret Howard and Robert Sackville, $2^{\text {nd }}$ Earl of Dorset. Married 1: Edward Seymour, Lord Beauchamp, 2: Sir Edward Lewis.

Sackville, Anne 1650-1722 Daughter of Frances Cranfield and Richard Sackville, $5^{\text {th }}$ Earl of Dorset. Married Alexander Home, $4^{\text {th }}$ Earl of Home.

Sackville, Cecily c. 1589-1624 Daughter of Margaret Howard and Robert Sackville, $2^{\text {nd }}$ Earl of Dorset. Married Henry Compton, her stepbrother. 
Sackville, Edward 1591-1652 $4^{\text {th }}$ Earl of Dorset, son of Margaret Howard and Robert Sackville, $2^{\text {nd }}$ Earl of Dorset. Married Mary Curzon.

Sackville, Edward 1624-1646 Son of Mary Curzon and Edward Sackville. Died in the custody of Parliamentary army. Never married.

Sackville, Isabella 1622-1661 Daughter of Anne Clifford and Richard Sackville. Married James Compton, $3^{\text {rd }}$ Earl of Northampton.

Sackville, John active 1616-1624 Gentleman servant to Richard Sackville, may be the grandson of Christopher Sackville, uncle of Thomas Sackville, $2^{\text {nd }}$ Earl of Dorset. He witnessed Richard Sackville's will.

Sackville, Margaret 1614-1676 Baroness Clifford suo jure, daughter of Anne Clifford and Richard Sackville. Married to John Tufton, $2^{\text {nd }}$ Earl of Thanet.

Sackville, Mary 1584-1613 Daughter of Cicely Baker and Thomas Sackville, $1^{\text {st }}$ Earl of Dorset and aunt to Richard Sackville. Married Henry Neville, $7^{\text {th }}$ Baron of Abergavenny.

Sackville, Richard 1568-1624 $3^{\text {rd }}$ Earl of Dorset, son of Margaret Howard and Robert Sackville, 2nd Earl of Dorset. Married Anne Clifford.

Sackville, Richard 1622-1677 $5^{\text {th }}$ Earl of Dorset, son of Mary Curzon and Edward Sackville, $4^{\text {th }}$ Earl of Dorset. Married Frances Cranfield.

Sackville, Richard 1649-1712 Son of Frances Cranfield and Richard Sackville, $5^{\text {th }}$ Earl of Dorset.

Sackville, Thomas 1536-1608 $1^{\text {st }}$ Earl of Dorset, Lord Treasurer to Queen Elizabeth, son of Winifred Bruges and Sir Richard Sackville. Married Cicely Baker. Grandfather of Richard Sackville.

Salkeld, John Fl 1657 Anne's tenant in Nether Brough, assumed the tenancy of James Walker. The Salkelds were an established Westmorland family.

Salvetti, Amerigo, also Allesandro Antelminelli c. 1572 - 1657 Tuscan ambassador and agent in England from 1616 to 1657 . He was a friend of Sir Henry Wotton. Married Frances Colbrand.

Sandford, John 1653-1717 Of Askham, son of Elizabeth Orfeur and Thomas Sandford. Married Mary Emersen.

Sandford, Richard d. $1675 \quad 2^{\text {nd }}$ Baronet Sandford of Howgill Castle, son of Bridget Dalston and Thomas Sandford, $1^{\text {st }}$ Baron Sandford. Married Mary Bowes. He served as Anne's deputy sheriff in 1647 .

Sandford, Thomas 1628-1677 Of Askham, son of John Sandford and Mary Aglionby. Married Elizabeth Orfeur.

Sandys, George 1578-1644 Writer and traveller, son of Cicely Wilford and Edwin Sandys, Archbishop of York. Married his father's ward, Elizabeth Norton.

Sandys, Hester d. 1656 Daughter of Miles Sandys. Married Sir Thomas Temple, $1^{\text {st }}$ Baron Stowe. Mother of fifteen children including Martha Temple, mistress of Richard Sackville.

Saunders, Thomas 1626-1670 MP, son of Margaret Evelyn and John Saunders of Woolstone Berkshire. Married 1: Anne Morris, 2: Anne Allen.

Scott, James 1649-1685 $1^{\text {st }}$ Duke of Monmouth, $1^{\text {st }}$ Duke of Buccleuch, son of Charles II of England and his mistress Lucy Walter. Married Anne Scott. Mistresses: 1. Eleanor Needham, 2 Henrietta Maria Wentworth, $6^{\text {th }}$ Baroness Wentworth.

Sedgewick, George 1618-1685 Of Collingfield, son of George Sedgewick of Killington, Anne's secretary and gentleman servant. 
Selby, William 1556-1638 Knight, of Ightham Mote, son of Margaret and Sir John Selby. Married Dorothy Bonham.

Seymour, Edward 1539-1621 $1^{\text {st }}$ Earl of Hertford, son of Anne Stanhope and Edward Seymour, $1^{\text {st }}$ Duke of Somerset, the brother of Queen Jane Seymour. Married 1: Catherine Grey, 2: Frances Howard, daughter of Lord William Howard of Effingham (d. 1598), 3: Frances Howard (Duchess of Lennox and Richmond, d. 1639).

Seymour, Edward 1561-1612 Lord Beauchamp, son of Catherine Grey and Edward Seymour, $1^{\text {st }}$ Earl of Hertford. Married Honora Rogers.

Seymour, Edward 1586-1618 Lord Beauchamp, son of Honora Rogers and Edward Seymour, ${ }^{\text {st }}$ Earl of Hertford. Married Anne Sackville, Richard Sackville's sister.

Seymour, Elizabeth d. 1603 Daughter of Anne Stanhope and Edward Seymour, ${ }^{\text {st }}$ Duke of Somerset. Married Richard Knightley of Fawsley Hall in Northamptonshire.

Seymour, Jane 1637-1679 Lady Dungarvan, daughter of Frances Devereux (d. 1674) and William Seymour, $2^{\text {nd }}$ Duke of Somerset. Married Charles Boyle, $3^{\text {rd }}$ Viscount Dungarvan.

Seymour, Mary 1637-1673 Countess of Winchilsea, daughter of Frances Devereux (1599-1674) and William Seymour, 2nd Duke of Somerset. Married Heneage Finch, $3^{\text {rd }}$ Earl of Winchilsea.

Seymour, William 1588-166o $\quad 2^{\text {nd }}$ Duke of Somerset, son of Honora Rogers and Edward Seymour, Lord Beauchamp. Married 1: Arbella Stuart, 2: Frances Devereux, daughter of Frances Walsingham and Robert Devereux, $2^{\text {nd }}$ Earl of Essex.

Sharshall, Margaret b. 1631 Wife of Samuel Grasty, mother of John Grasty.

Sheffield, Edmund 1564-1646 $1^{\text {st }}$ Earl of Mulgrave, son of Douglas Howard and John Sheffield, $2^{\text {nd }}$ Baron Sheffield. Married 1: Ursula Tyrwhitt, 2: Mariana Irwin.

Sherburne, Edwin 1578-1641 Served Dudley Carlton as a financial agent, later in the service of Francis Bacon, $1^{\text {st }}$ Viscount St Alban. Married Mary Turner.

Sidney, Barbara 'Babs' 1599-1643 Daughter of Barbara Gamage and Robert Sidney, Viscount De L'Isle and $1^{\text {st }}$ Earl of Leicester. Married 1: Thomas Smythe, Viscount Strangeford, 2: Sir Thomas Culpeper.

Sidney, Mary 1561-1521 Poet, literary patron, daughter of Mary Dudley and Sir Henry Sidney. Married Henry Herbert, $2^{\text {nd }}$ Earl of Pembroke. Anne married her son, Philip.

Sidney [Wroth], Mary 1587-1651 Poet, wrote The Countess of Montgomery's Urania, the sonnet sequence Pamphilia to Amphilanthus and the play Love's Victory, daughter of Barbara Gamage and Robert Sidney, $1^{\text {st }}$ Earl of Leicester. Married Sir Robert Wroth of Loughton Hall. Long-term liaison with William Herbert, $3^{\text {rd }}$ Earl of Pembroke.

Sidney, Robert 1563-1626 Viscount de L'Isle and $1^{\text {st }}$ Earl of Leicester, son of Mary Dudley and Sir Henry Sidney. Married Barbara Gamage.

Sidney, Robert 'Robin' 1595-1677 $2^{\text {nd }}$ Earl of Leicester, son of Barbara Gamage and Robert Sidney, $1^{\text {st }}$ Earl of Leicester. Married Dorothy Percy.

Simpton, Judith active 1616-1624 Anne's maid at Knole.

Sisley, Jane active 1616-1624 Nursery maid at Knole.

Skinne, Mr active 1619 Likely servant at Knole. Married Sarah (maiden name unknown) in St Bride's church, London, 1 May 1619.

Skinne, Sarah Likely servant at Knole. Married in St Bride's church, London, 1 May 1619.

Sleddall, Jane active 1675-1676 Anne's laundry maid. 
Slingsby, Francis active 1568-1619 Knight of Scriven, Yorkshire. Captain on George Clifford's Puerto Rico expedition, son of Mary Percy and Francis Slingsby.

Smallwood, Alan 1608-1686 Rector of Greystoke, Cumberland, son of Jane Garnett and Thomas Smallwood. Married Dorothy Pursglove.

Smith, Leonard active 1667-1676 Alderman and mayor of Appleby, a governor of Appleby Grammar School. Married Dulcibel Smith.

Smith, William active 1616-1624 Yeoman of the Buttery at Knole.

Smyth, Elizabeth d. 1702 Daughter of Dr Henry Smyth, master of Magdalene College, Cambridge. Married Edward Rainbow, also master of Magdalene College and later Bishop of Carlisle. Aunt of Edward Hasell, one of Anne's gentlemen officers.

Somerset, Edward 1553-1628 $4^{\text {th }}$ Earl of Worcester, son of Christian North and William Somerset, $3^{\text {rd }}$ Earl of Worcester. Married Elizabeth Hastings.

Somerset, Elizabeth 1618-1684 Daughter of Anne Russell and Henry Somerset, $1^{\text {st }}$ Marquess of Worcester. Married Francis Browne, $3^{\text {rd }}$ Viscount Montagu.

Somerset, Henry 1577-1646 $1^{\text {st }}$ Marquess of Worcester, son of Elizabeth Hastings and Edward Somerset, 4th Earl of Worcester. Married Anne Russell.

Somerset, Katherine 1585-1654 Daughter of Elizabeth Hastings and Edward Somerset, $4^{\text {th }}$ Earl of Worcester. Married Sir Thomas Windsor, $6^{\text {th }}$ Baron Windsor.

Sort, Edmund active 1676 Anne's household servant in Westmorland.

Spedding, Margaret active $\mathbf{1 6 7 6}$ Perhaps wife to John Spedding of Kirkbarrow, Westmorland, brother of Anne's tenant William Spedding,

Spedding, William active 1670-1676 Anne's tenant, and substantial farmer in Brougham.

Spencer, Alice 1559-1637 Daughter of Catherine Kitson and Sir John Spencer. Married 1: Ferdinando Stanley, $5^{\text {th }}$ Earl of Derby, 2: Thomas Egerton, $1^{\text {st }}$ Viscount Brackley.

Spencer, Anne d. 1618 Daughter of Catherine Kitson and Sir John Spencer of Althorp. Married 1: William Stanley, $3^{\text {rd }}$ Baron Monteagle, 2: Henry Compton, $1^{\text {st }}$ Baron Compton, 3: Robert Sackville, $2^{\text {nd }}$ Earl of Dorset.

Spencer, Mary c. 1586-1631 Daughter of Margaret Bower and Sir William Spencer. Married Maximillian Dallison of Halling, Kent.

Spencer, Robert 1570-1627 $1^{\text {st }}$ Baron Spencer of Wormleighton, owner of Althorp, Northamptonshire, son of Mary Catlyn and Sir John Spencer. Married Margaret Willoughby.

St John, Alice b. c. 1622 Daughter of Margaret Waldegrave and John St John. Married Edmund Elmes. Raised Margaret Russell during her childhood.

St John, Anne c. 1580-1638 Daughter of Catherine Dormer and John St John, $2^{\text {nd }}$ Baron. Married William Howard, 3rd Baron Howard of Effingham.

St John, Oliver 1559-1630 $1^{\text {st }}$ Viscount Grandison, Lord Deputy of Ireland, son of Elizabeth Blount and Nicholas St John.

St John, Oliver 1598-1673 Judge, son of Sarah Buckley and Oliver St John. Married 1: Joanna Altham, 2: Elizabeth Cromwell.

St Leger, Thomas 1581-1631 Son of Sir Anthony St Leger and Mary Scott.

Stanley, Charles 1628-1672 $8^{\text {th }}$ Earl of Derby, son of Charlotte de La Trémouille and James Stanley, $7^{\text {th }}$ Earl of Derby. Married Dorothea Helena Kirkhoven.

Stanley, Ferdinando 1559-1594 $5^{\text {th }}$ Earl of Derby, son of Margaret Clifford and Henry Stanley, $4^{\text {th }}$ Earl of Derby. Married Alice Spencer. 
Stanley, Frances 1583-1636 Daughter of Alice Spencer and Ferdinando Stanley, $5^{\text {th }}$ Earl of Derby. Married John Egerton, $1^{\text {st }}$ Earl of Bridgewater.

Stanley, Robert d. after 1673 Son of Dorothea Helena Kirkhoven and Charles Stanley, $8^{\text {th }}$ Earl of Derby. Never married.

Stanley, William 1561-1642 $6^{\text {th }}$ Earl of Derby, son of Margaret Clifford and Henry Stanley, $4^{\text {th }}$ Earl Derby. Married Elizabeth de Vere.

Stanley, William 1655-1702 $9^{\text {th }}$ Earl of Derby, son of Dorothea Helena Kirkhoven and Charles Stanley, $8^{\text {th }}$ Earl of Derby. Married Elizabeth Butler.

Steele, William 1610-1680 Baron of the Exchequer and Lord Chancellor of Ireland, son of Cecily Shaw and Richard Steele. Married 1: Elizabeth Godfrey, 2: Mary Mellish.

Stewart, Patrick c. 1566-1615 $2^{\text {nd }}$ Earl of Orkney, son of Jean Kennedy and Robert, $1^{\text {st }}$ Earl of Orkney. Married Margaret Livingston. Executed for treason in 1615.

Stidolph, Francis Of Norbury, Surrey, son of Thomas Stidolph and Elizabeth Hussey. Married Mary Altham.

Strickland, Allan active 1669-1676 Anne Clifford's steward in Westmorland.

Strickland, Thomas active 1663-1676 Gentleman officer for Anne Clifford and receiver of her rents in Westmorland. Married Dorothy, had two daughters Anne and Ursula and one son James.

Stuart, Arbella 1575-1615 Daughter of Charles Stuart, Earl of Lennox, and Elizabeth Cavendish, granddaughter to Elizabeth Hardwick, Countess of Shrewsbury (Bess of Hardwick), first cousin to James I, and claimant to the crown of England. Married William Seymour and died in the Tower of London in 1615.

Stuart, Elizabeth 1596-1662 Princess Royal, daughter of Anne of Denmark and James I. Married Frederick V, Elector Palatine, King of Bohemia.

Stuart, Elizabeth 1610-1673 Daughter of Katherine Clifton, $2^{\text {nd }}$ Baroness Clifton suo jure and Esmé Stewart, $3^{\text {rd }}$ Duke of Lennox. Married Henry Frederick Howard, Earl of Arundel.

Stuart, Henry 1594-1612 Prince of Wales, son of Anne of Denmark and James I.

Stuart, Henry 1640-166o Duke of Gloucester, son of Henrietta Maria of France and Charles I of England.

Stuart, James 1633-1701 King James II of England, son of Henrietta Maria of France and Charles I of England. Married 1: Anne Hyde, 2: Mary of Modena.

Stuart, Ludovick 1574-1624 $2^{\text {nd }}$ Duke of Lennox and Duke of Richmond, son of Catherine de Balsac and Esmé Stuart, $1^{\text {st }}$ Duke of Lennox. Married Sophia Ruthven.

Stuart, Mary 1631-1660 Princess Royal, daughter of Henrietta Maria of France and Charles I, King of England. Married William II of Orange.

Suckling, John (the elder) 1569-1627 Knight, son of Elizabeth Barwick and Robert Suckling, one-time Mayor of Norwich. Married Martha Cranfield. His son was the poet Sir John Suckling (the younger).

Sutton, Margaret b. c. 1590 Daughter of Theodosia Harington and Edward Sutton, $5^{\text {th }}$ Baron Dudley. Married Sir Miles Hobart.

Sutton, Mary 1586-1645 Daughter of Theodosia Harington and Edward Sutton, $5^{\text {th }}$ Baron Dudley. Married Alexander Home, $1^{\text {st }}$ Earl of Home.

Sutton, Mrs d. 1676 The mother or superintendent of Anne's almshouse at Beamsley, Yorkshire.

Swarton, Sarah active 1617-1619 Servant of Anne Lake, participated in the libellous 
activities directed at William Cecil, Lord Ros and Frances Brydges, Countess of Exeter, in Lake/Ros scandal.

Swindin, Arthur d. 1676 Son of John Swindin, began in Anne's service as her fisher boy at least by 1665 . In 1675 listed as a kitchen servant.

Symondson, John active 1667 Of Old Hall, Starbotton, Yorkshire, gentleman servant of Richard Boyle, $2^{\text {nd }}$ Earl of Cork. Possibly son of Lister Symondson, Keeper of the Deer at Buckden.

Talbot, Alethea 1585-1564 Art collector and literary patron, daughter of Mary Cavendish and Gilbert Talbot, $7^{\text {th }}$ Earl of Shrewsbury. Married Thomas Howard, Earl of Arundel, $4^{\text {th }}$ Earl of Surrey and $1^{\text {st }}$ Earl of Norfolk.

Talbot, Elizabeth 1582-1651 Countess of Kent, daughter of Mary Cavendish and Gilbert Talbot, $7^{\text {th }}$ Earl of Shrewsbury. Married 1: Henry Grey, $8^{\text {th }}$ Earl of Kent, 2: possibly the antiquarian John Selden.

Talbot, Gilbert 1562-1616 $\quad 7^{\text {th }}$ Earl of Shrewsbury, son of Gertrude Manners and George Talbot, 6th Earl of Shrewsbury. Married Mary Cavendish.

Talbot, Mary c. 1594-1650 Daughter of Mary Cavendish and Gilbert Talbot, $7^{\text {th }}$ Earl of Shrewsbury. Married William Herbert, $3^{\text {rd }}$ Earl of Pembroke.

Tassis, Juan de d. 1607 2nd Count of Villamediana, leader of the delegation that brokered the 1604 peace treaty between England and Spain.

Taylor, Ann active 1595-1603 Anne's childhood governess, daughter of Mr Cholmley (a relation of Anne's). She married William Taylor and had a number of children by him who did not survive into adulthood.

Taylor, John active 1606-1619 Gentleman servant to George Clifford and Francis Clifford.

Taylor, Thomas active 1606-1619 Gentleman servant to George Clifford, Anne's father, and Francis Clifford.

Temple, Anne b. 1630 Maid of honour to Catherine of Braganza, Queen consort of England, daughter and co-heir of Rebecca Carew and Thomas Temple of Frankton, Warwickshire. Married Sir Charles Littleton.

Temple, Martha d. 1620 Daughter of Hester Sandys and Sir Thomas Temple, $1^{\text {st }}$ Baron Stowe. Married Sir Thomas Penyston. Richard Sackville's mistress.

Thatcher (or Thacker), Mr active 1619 Possibly Gilbert Thacker of Repton, Derbyshire, or Godfrey Thacker of Repton, high sheriff of Derbyshire (appt. 1619).

Thorpe, Francis 1595-1665 Baron of the Exchequer, assize judge, son of Elizabeth Danyell of Beswick and Roger Thorpe of Birdsall, North Yorkshire.

Throckmorton, Elizabeth 'Bess' 1565-1647 A maid of honour to Elizabeth I, daughter of Anne Vaux and Sir Nicholas Throckmorton. Married Sir Walter Raleigh.

Thwaites, John, the younger d. 1698 An alderman and mayor of Appleby.

Todd, Thomas active $\mathbf{1 6 1 6}$ Of Westmorland, servant to Margaret Russell.

Trenchard, Thomas 1582-1657 Knight, son of Anne Speke and Sir George Trenchard. Married Elizabeth Morgan.

Tufton, Anne b. and d. 1634 Infant daughter of Margaret Sackville and John Tufton, $2^{\text {nd }}$ Earl of Thanet.

Tufton, Anne 1654-1713 Daughter of Margaret Sackville and John Tufton, $2^{\text {nd }}$ Earl of Thanet. Married Sir Samuel Grimston.

Tufton, Cecil 1519-1682 Son of Frances Cecil and Sir Nicholas Tufton, $1^{\text {st }}$ Earl of Thanet. Married Mary Lloyd. 
Tufton, Cecily 1648-1672 Daughter of Margaret Sackville and John Tufton, $2^{\text {nd }}$ Earl of Thanet. Married Christopher, $1^{\text {st }}$ Viscount Hatton.

Tufton, Cecily d. 1653 Daughter of Christian Browne and Sir John Tufton, $1^{\text {st }}$ Baronet Tufton. Married Francis Manners, $6^{\text {th }}$ Earl of Rutland.

Tufton, Charles b. c. 1645 Knight, son of Mary Lloyd and Cecil Tufton.

Tufton, Diana b. c. 1610, d. after 1671 Daughter of Frances Cecil and Sir Nicholas Tufton, $1^{\text {st }}$ Earl of Thanet. Married Sir Robert Curson of Witer-Prye, Oxford.

Tufton, Frances 1642-1666 Daughter of Margaret Sackville and John Tufton, $2^{\text {nd }}$ Earl of Thanet. Married Henry Drax and died in childbirth with her first child.

Tufton, George 1650-1670 Son of Margaret Sackville and John Tufton, $2^{\text {nd }}$ Earl of Thanet and Anne's grandson. Never married.

Tufton, John 1608-1664 $2^{\text {nd }}$ Earl of Thanet, son of Frances Cecil and Nicholas Tufton, $1^{\text {st }}$ Earl of Thanet. Married Margaret Sackville.

Tufton, John 1638-1680 $\quad 4^{\text {th }}$ Earl of Thanet, son of Margaret Sackville and John Tufton, $2^{\text {nd }}$ Earl of Thanet. Inherited the Clifford hereditary lands. Never married.

Tufton, Margaret 1636 - after 1676 Daughter of Margaret Sackville and John Tufton, $2^{\text {nd }}$ Earl of Thanet. Married George, $3^{\text {rd }}$ Baron Coventry.

Tufton, Mary 1651-1674 Daughter of Margaret Sackville and John Tufton, $2^{\text {nd }}$ Earl of Thanet. Married Sir William Walter.

Tufton, Nicholas 1578-1631 $1^{\text {st }}$ Earl of Thanet, son of Christian Browne and Sir John Tufton, $1^{\text {st }}$ Baronet Tufton. Married Frances Cecil.

Tufton, Nicholas 1631-1639 $3^{\text {rd }}$ Earl of Thanet, son of Margaret Sackville and John Tufton, $2^{\text {nd }}$ Earl of Thanet. Married Elizabeth Boyle, his second cousin. Inherited the Clifford hereditary lands.

Tufton, Richard 1640-1684 $5^{\text {th }}$ Earl of Thanet, son of Margaret Sackville and John Tufton, $2^{\text {nd }}$ Earl of Thanet. Inherited the Clifford hereditary lands.

Tufton, Sackville 1646-1721 Son of Margaret Sackville and John Tufton, $2^{\text {nd }}$ Earl of Thanet. Married Elizabeth Wilbraham. Their son Sackville became $7^{\text {th }}$ Lord Tufton and inherited the Clifford hereditary lands.

Tufton, Thomas 1644-1729 $6^{\text {th }}$ Earl of Thanet and Baron Clifford, son of Margaret Sackville and John Tufton, $2^{\text {nd }}$ Earl of Thanet. Inherited the Clifford hereditary lands. Married Catherine Cavendish.

Turner, Elizabeth c. 1635 - after 1663. Daughter of Elizabeth Nicholls and John Turner. Married 1: Mr Kellaway, 2: Mr Green.

Turner, John d. 1663 One of Anne's gentlemen officers, receiver of her jointure rents in Kent. Married Elizabeth Nicholls, Anne's former gentlewoman servant.

Turnor, Christopher 1607-1675 Knight, assize judge, son of Ellen Samm and Christopher Turnor. Married Joyce Warwick.

Twentyman, John active 1670 os Gardener for the Bishop of Carlisle, Edward Rainbow, at Rose Castle near Carlisle. Works on Anne's gardens in 1670 .

Twisden, Thomas 1602-1683 $1^{\text {st }}$ Baronet, son of Anne Finch and Sir William Twysden. Married Jane Thomlinson of Whitby, Yorkshire.

Tyrwhitt, Ursula c. 1565-1617 Daughter of Elizabeth Oxenbridge and Sir Robert Tyrwhitt of Kettelby. Married Sir Edmund Sheffield, $1^{\text {st }}$ Earl of Musgrave.

Ubank, Thomas active 1675-1676 Physician. He served the Clifford household from at least 1675. Married the widow Mrs Hilton.

Uvedale, Elizabeth 1646-1696 Daughter and co-heir of Victoria Cary (daughter of 
Elizabeth Tanfield, writer and playwright) and Sir William Uvedale. Married 1: Sir William Berkeley, 2: Edward Howard, $2^{\text {nd }}$ Earl of Carlisle.

Vane, Henry 1589-1655 Knight, son of Margaret Twysden and Henry Vane of Hadlow, Kent. Married Frances Darcy, daughter of Thomas Darcy of Tolleshurst Darcy, Essex.

Vaux, Edward 1591-1661 $\quad 4^{\text {th }}$ Baron of Harrowden, son of Elizabeth Roper and George Vaux. Married Elizabeth Howard (daughter of Thomas Howard, $1^{\text {st }}$ Earl of Suffolk).

Vavasour, Anne active 1601-1603 Gentlewoman of the privy chamber during Elizabeth I. Married Sir Richard Warburton.

Vavasour, Catherine b. c. 1595 Daughter of Katherine Coupe and Sir Peter Vavasour. Married Sir Thomas Glemham.

Vernon, Elizabeth 1572-1655 Maid of Honour to Elizabeth I, daughter of Elizabeth Devereux and John Vernon. Married Henry Wriothesley, $3^{\text {rd }}$ Earl of Southampton.

Veteripont, Idonea c. 1261-1333 Lady of Pendragon and Brough castles suo jure, daughter and co-heir of Isabella FitzGeoffrey and Robert, $3^{\text {rd }}$ Lord Veteripont. Married 1: Roger de Leyburne, 2: John de Cromwell.

Veteripont, Isabella 1254-1291 Sheriff of Westmorland and Lady of Appleby and Brougham castles suo jure, daughter and co-heir to Isabella FitzGeoffrey and Robert, $3^{\text {rd }}$ Lord Veteripont. Married Roger de Clifford III.

Villiers, George 1592-1628 $\quad 1^{\text {st }}$ Duke of Buckingham and favourite of James I, son of Mary Beaumont and George Villiers. Married Katherine Manners, Baroness de Ros suo jure. Assassinated in 1628.

Villiers, Susan d. 1655 Daughter of Mary Beaumont and Sir George Villiers, Sister of George Villiers, ${ }^{\text {st }}$ Duke of Buckingham. Married William Fielding $1^{\text {st }}$ Earl of Denbigh.

Vincent, Gabriel d. 1665 Anne's steward and chief gentleman officer. He managed her building works in the north.

Wade, Cuthbert 1619 - after 1666 Captain of Horse in the army of Charles I, son of Christopher Cuthbert of Kinsley Old Hall. Married 1: Agnes Bracken, 2: Dorothy Malham, 3: Frances Beilby.

Walker, Isaac active 1665-1676 Groom of Anne's stables in Westmorland.

Walker, James active 1655-1657 Likely of Sharrow Bay, near Penrith, Anne's tenant in Nether Brough. Anne ejected him from his tenancy after a legal dispute.

Waller, Thomas active 1669 Serjeant at law and assize judge, son of Thomas Waller of Gregories, Buckinghamshire.

Wallop, Henry, 1568-1642 Knight, of Farleigh Wallop in Hampshire, Sheriff of Hampshire. Married Elizabeth Corbet.

Walter, David c. 1610 - c. 1678 Son of Margaret Offlet and Sir John Walter. Married Elizabeth Bayning, Countess of Sheppey suo jure.

Walter, John 1566-1630 Lawyer, Chief Baron of the Exchequer, worked for Richard Sackville, son of Edmund Walter, Chief Baron of the Exchequer.

Walter, John active 1668 Servant to John Gilmore, Anne's Keeper of Whinfell forest.

Walter, John 1674-1722 $3^{\text {rd }}$ Baronet, MP for Appleby, son of Mary Tufton and Sir William Walter, $2^{\text {nd }}$ Baronet. Married Elizabeth Vernon.

Walter, Mr active 1616 Lawyer, worked for Richard Sackville.

Walter, William 1604-1675 $1^{\text {st }}$ Baronet, Chief Baron of the Exchequer, son of Margaret Offlet and Sir John Walter. Married Elizabeth Lucas.

Walter, William d. $1694 \quad 2^{\text {nd }}$ Baronet, son of Elizabeth Lucas and Sir William Walter, $1^{\text {st }}$ Baronet. Married Mary Tufton. 
Warburton, Peter 1588-1666 Lawyer, assize judge, son of Magdalen Moulton and Peter Warburton of Hefferston Grange, Cheshire. Married (likely as second wife) Alice Gardiner.

Warburton, Richard d. 1610 Knight, Constable of Lancaster Castle, son of Alice Cooper and Peter Warburton of Hefferston Grange, Cheshire. Married Anne Vavasour.

Waste, Thomas active 1619 A servant of Richard Sackville.

Watson, Edward 1549-1617 Knight of Rockingham Castle, Leicestershire, son of Dorothy Montagu and Edward Watson of Rockingham. Married Anne Digby.

Watson, Elizabeth b. c. 1570 Gentlewoman servant to Anne Russell, Countess of Warwick, daughter of Anne Digby and Edward Watson of Rockingham Castle. Married 1: Sir John Needham, 2: Sir Edward Tyrrell, $1^{\text {st }}$ Baronet of Thornton.

Watson, Lewis 1584-1653 $1^{\text {st }}$ Baron Rockingham, son of Anne Digby and Sir Edward Watson of Rockingham Castle. Married 1: Catherine Bertie, 2: Eleanor Manners.

Watson, Mrs active 1617 Likely related to the Watson family of Rockingham Castle.

Waugh, Margaret c. 1635 - after 1676 Anne's gentlewoman servant in Westmorland. Married John Waugh, a yeoman farmer in Appleby. Her son John Waugh became Bishop of Carlisle in 1723 .

Webb, Gregoryactive 1603 Of Wantage, Oxfordshire, town bailiff and tenant of William Boucher, $3^{\text {rd }}$ Earl of Bath.

Webster, Dorothy d. after 1676 Daughter of Isabel Webster, sister to John Webster. Married John Winter, Rector of Clifton,

Webster, John active 1670-1676 Anne's tenant farmer in Brougham, son of Isabel Webster. May also be Anne's woodward of Whinfell and Flakebridge forest, builder who oversees work for her.

Wells, John active 1666-1719 Appointed curate of St Botolph without Aldersgate, 1666, later Rector of Hanwell, and of Hanworth, St Paul's Cathedral, Prebend of Harleston.

Wenman, Richard 1573-1640 $1^{\text {st }}$ Viscount Wenman, son of Jane West and Sir Thomas Burke. Married 1: Agnes Fermor (writer and translator), 2: Alice Chamberlain, 3: Elizabeth (maiden name unknown), 4: Mary Keble.

Wentworth, John c. 1583-1631 $1^{\text {st }}$ Baronet, of Gosfield, Essex, son of Cecelia Unton and John Wentworth. Married Catherine Wentworth.

Whalley, Thomas active 1671-1676 Servant to George Sedgewick.

Wharton, Anne 1640-1689 Daughter of Jane Goodwin and Philip $4^{\text {th }}$ Baron Wharton. She was goddaughter to Anne. Married William Carr.

Wharton, Elizabeth d. 1669 Daughter of Elizabeth Wandesford and Philip Wharton, $4^{\text {th }}$ Baron Wharton. Married Robert Bertie, $3^{\text {rd }}$ Earl of Lindsey.

Wharton, George 1583-1609 Son of Frances Clifford and Philip $3^{\text {rd }}$ Baron Wharton. Killed in a duel with Sir James Stewart, Master of Blantyre.

Wharton, Goodwin 1653-1704 Son of Jane Goodwin and Philip, $4^{\text {th }}$ Baron Wharton. Never married. Mistress, the medium Mary Parish.

Wharton, Hugh active 1676-1681 Steward of Philip, $4^{\text {th }}$ Baron Wharton.

Wharton, Margaret 1581-1659 Daughter of Frances Clifford and Philip, $3{ }^{\text {rd }}$ Baron Wharton. Married Sir Edward Wotton.

Wharton, Margaret c. 1643 - after 1695 Daughter of Jane Goodwin and Philip, $4^{\text {th }}$ Baron Wharton. Married 1: a Major Dunch, 2: Sir Thomas Sulyarde, 3: William Ross, $12^{\text {th }}$ Lord Ross. 
Wharton, Mary 1655-1701 Daughter of Jane Goodwin and Philip, $4^{\text {th }}$ Baron Wharton. Married Sir Charles Kemys, $4^{\text {th }}$ Baronet Kemys.

Wharton, Philip 1613-1696 $4^{\text {th }}$ Baron Wharton, son of Philadelphia Carey and Sir Thomas Wharton of Aske Hall. Married 1: Elizabeth Wandesford, 2: Jane Goodwin, 3: Anne Carr.

Wharton, Thomas c. 1615-1684 Son of Philadelphia Carey and Sir Thomas Wharton of Aske Hall. Married 1: Mary Carey, 2: Jane Robinson. He was brother to Philip, $4^{\text {th }}$ Baron Wharton.

Wharton, Thomas 1648-1715 $5^{\text {th }}$ Baron Wharton, $1^{\text {st }}$ Marquis Wharton, son of Jane Goodwin and Philip, 4th Baron Wharton. Married Anne Lee, a poet, 2: Lucy Loftus.

Whitchard, Alexander d. 1659 Gentleman servant to John Tufton, $4^{\text {th }}$ Earl of Tufton, during Tufton's youth and during his European tour.

Whittington, Timothy active $\mathbf{1 6 1 6}$ A knight and a lawyer.

Wilde, William 1611-1679 $1^{\text {st }}$ Baronet, assize judge, son of William Wilde, a vintner of Bread Street, London. Married 1: Hannah Terry, 2: Jane Wilson, 3: Frances Barcroft.

William II, Prince of Orange 1626-1650 Son of Frederick Henry, Prince of Orange and Amalia of Solms-Braunfels. Married Princess Royal, Mary Stuart, daughter of Charles I.

William III 1650-1702 Prince of Orange and King of England, son of Mary Princess Royal of England, daughter of Henrietta Maria and Charles I, and William II of Orange. Married his first cousin, Mary Stuart, later Mary II of England, who was the daughter of Anne Hyde and James, Duke of York, later James II of England.

Williams, John d. 1619 Lawyer, author of Balaam's Ass (1613), executed for sedition in 1619. Married Anne Weston of the Westons of Roxwell.

Willison, Robert active 1676 Of Penrith, Wine merchant and Postmaster.

Willoughby, Mistress active 1616-1624 Anne's gentlewoman servant at Knole.

Windham, Hugh 1603-1684. Knight, Baron of the Exchequer, Common Pleas and assize judge, son of Joan Portman and Orchard Wyndham. Married 1: Jane Wodehouse, 2: Elizabeth Mynne, 3: Katherine Fleming.

Woodgate, Thomas d. 1647 Yeoman of East Grinstead, Sussex, Yeoman of the Great Chamber at Knole (upper household servant).

Woolrich, William active 1617 Gentleman of Sussex. Married Anne Wharton, daughter of Thomas Wharton, $2^{\text {nd }}$ Baron Wharton.

Worleigh, Mr active 1616-1617 Gentleman servant of Margaret Russell, and tenant of the Cliffords in Westmorland.

Wray, Frances d. 1634 Daughter of Anne Girlington and Christopher Wray. Married: 1. George St Poll, 2. Robert Rich, $1^{\text {st }}$ Earl of Warwick.

Wray, James active 1590-1619 Likely son of Anne Girlington and Christopher Wray, or a near relation.

Wright, Rowland d. 1671 Clergyman appointed to Mallerstang chapel in 1660 by Anne Clifford.

Wright, Thomas d. 1678 A Quaker of Castlethwaite, Westmorland. Married Dorothy (maiden name unknown). Anne purchased malt from him.

Wriothesley, Henry 1573-1624 $3^{\text {rd }}$ Earl of Southampton, son of Mary Browne and Henry Wriothesley, $2^{\text {nd }}$ Earl of Southampton. Married Elizabeth Vernon.

Wriothesley, Rachel c. 1636-1723 Lady Russell, the daughter of Rachel de Massue and Thomas Wriothesley, $4^{\text {th }}$ Earl of Southampton. Married 1: Francis, Lord Vaughan; 2: 
William, Lord Russell, who was executed for alleged involvement in the Rye House Plot of 1683 .

Wroth, Thomas 1584-1672 Knight, lawyer, active in the Virginia Company, son of Joan Bulmer and Thomas Wroth. Married Margaret Rich.

Yaxley, Robert 1560-1629 Knight, under command at Berwick under George and/or Francis Clifford, son of Rose Langton and William Yaxley. Never married.

Yelverton, Francis d. 1684 Daughter of Susan Longueville, suo jure Baroness Grey of Ruthin, and Henry Yelverton, $2^{\text {nd }}$ Baronet. Married Christopher Hatton.

Yelverton, Henry 1566-1630 Knight, lawyer, son of Margaret Catesby and Sir Christopher Yelverton. Married Mary Beale.

Zouche, Edward d. 1634 Knight Marshal of the Royal Household, son of Sir William Zouche. Married Dorothea Silking of Denmark, a lady of Queen Anne's bedchamber. Zouche, Edward la 1556-1625 $11^{\text {th }}$ Baron Zouche, son of Margaret Welby and George la Zouche, $10^{\text {th }}$ Baron Zouche. Married 1: his cousin Eleanor, daughter of Sir John Zouche, 2: Sarah Harrington. 